\title{
Geoquímica e ambiência tectônica do arco magmático de Pereiro, região NE da Província Borborema
}

\author{
Christiano Magini' ${ }^{1}$ \& Peter C. Hackspacher ${ }^{2}$
}

\begin{abstract}
Resumo Arcos magmáticos Neoproterozóicos estão edificados em todos continentes. Os modelos de geração destes arcos estão predominantementes associados a eventos tectonotermais que envolveram a fusão de crosta continental, crosta oceânica e em alguns casos material do manto superior. Durante a edificação as condições tectônicas podem variar desde o fácies xisto verde até granulito. Na porção NE da Província Borborema granitos Neoproterozóicos na região de Pereiro, sudoeste do estado do Ceará, formam um arco magmático composto por duas suítes. As suítes são geoquimicamente distintas com magmas ácidos e básicos, respectivamente classificados como magmas subalcalinos a alcalinos. A integração dos dados geoquímicos possibilitou a determinação de dois pulsos magmáticos denominados de Suíte São Miguel (SSM) e Suíte Dr. Severiano(SDS). Os pulsos magmáticos evoluíram sob dois regimes deformacionais e metamórficos distintos, durante a Orogênese Brasiliana. A SSM mais antiga, sofreu metamorfismo de alto grau atingindo condições de anatexia. Microtexturas tais como: crescimento de limite de grão, recristalização de feldspatos e anfibólios, formação de fundido, confirmam uma deformação dúctil no fácies anfibolito superior. A SDS, mais recente, sofreu metamorfismo de baixo grau (xisto verde). Análises geocronológicas comparativa entre valores de eNd destes dois pulsos confirmam a existência de fontes distintas. Idades U/Pb em zircões dos plutons São Miguel/Pereiro e Padre Cosme confirmam a idade Neoproterozóica. Concluímos que o arco magmático de Pereiro foi edificado durante o Ciclo Brasiliano com seu clímax plutônico associado à formação da SSM (570 Ma.) em regime dúctil passando para condições de médio a baixo grau (xisto verde) em regime rúptil durante a colocação da SDS (540Ma).
\end{abstract}

Palavras-chave: Arcos Magmáticos, Província Borborema, Neoproterozóico.

\begin{abstract}
Abstrac Geochemistry and tectonic settings of Pereiro magmatic arc, NE region Borborema Province Neoproterozoic magmatic arcs are widespread in all continents. Their collocation models are mainly associated with tectonothermal events varying from the greenschists to granulitic conditions and envolving fusion of continental and oceanic crust and some cases upper mantle parts. In the NE portion of the Borborema Province, Pereiro region in south west portion of Ceara state Neoproterozoic granites compound two suites. The suites are distinctive by geochemical represented by felsic and basic magmas of subalkaline to alkaline nature. Integration of geochemical results determine two pulses denominated Suite São Miguel (SSM) and Suite dr Severiano (SDS). The pulses developed two distintic deformational and metamorphic regimes during Brasilian Orogeny. The oldest suite SSM suffer high grade metamorphic with anatexi conditions. Microtextures by grain boudaring, feldspar and anfibole recristalization and anatetic melt represent by ductile conditions deformation in upper anfibolite facies. The SDS more young suffer only green schist metamorphism. The chronological variation expressed through eNd confirm two intrusive pulses and distinct resources. U/Pb ages in zircons of plutons São Miguel and Padre Cosme confirm the magmatic arc related to the Neoproterozoic. The conclusions are: the Pereiro magmatic arc is edifcated in Brasilian Orogey with had a magmatic climax correspondent to the SMS (570 Ma.) under ductile strain regime and low grade metamorphic conditions and finally a ruptil regime during the DSS intrusion (540Ma).
\end{abstract}

Keywords: Magmatic Arc, Borborema Province, Neoproterozoic.

INTRODUÇÃO A Província Borborema tem como último evento orogenético o Ciclo Brasiliano, durante este evento inúmeros corpos graníticos intrudiram na crosta continental, evidenciando o climax do evento orogenético e magmático. Neste magmatismo foram gerados plutons com diferentes composições, em diferentes condições de colocação, formados a partir de diferentes protólitos. Pesquisamos no Arco Magmático de Pereiro sua assinatura geoquímica e isotópica, através de geoquí- mica total e geocronologia $\mathrm{Sm} / \mathrm{Nd}$ e $\mathrm{U} / \mathrm{Pb}$. Com auxílio da interpretação estrutural e relações de campo além da geoquímica e geocronologia, buscamos integrar os resultados para melhor compreender o processo de geração e colocação dos magmas durante uma orogênse. $\mathrm{O}$ entendimento de extensas áreas plutônicas permitirá correlações entre batólitos e/ou arcos magmáticos descritos na porção setentrional da Província Borborema como por exemplo Arco Magmático de Santa Quitéria - CE ou 
Batólito/Maciço de Acari - RN, dentre outros. Através desta correlação objetivamos num futuro próximo evidenciar diferentes modelos de geração e colocação sob influência dos protólitos, tipo de colocação, profundidade, assinatura geoquímica, onde o produto final, magmas Edicarianos possam ser melhor compreendidos.

ARCABOUÇO GEOLÓGICO A área pesquisada engloba $3000 \mathrm{Km}^{2}$, localiza-se no Domínio Rio Grande do Norte (Fetter 1999, Schmus et al. 2003), entre os limites dos estados do Ceará e Rio Grande do Norte, distando $400 \mathrm{Km}$ da cidade de Natal (Fig. 1).

A geologia da região é composta por três unidades litoestratigráficas: ortognaisses plutônicos de idade Paleoproterozóica Inferior, Período Riaciano, Complexo Pau dos Ferros; metassedimentos e metavulcânicas alcalinas de idade Estateriana, Grupo São José (Sá et al. 1981) e granitóides plutônicos cálcio-alcalinos de alto potássio de idade Edicariana Arco Magmático de Pereiro (Magini e Hackspacher 2006). Neste intervalo do pré-Cambriano se descatam processos de acresção de arcos de ilhas durante o Paleoproterozóico $2.2-2.0 \mathrm{Ga}$ (Martins 2003 e Castro 2001), colisão contiental com amplo plutonismo granítico no Edicariano (600 Ma), além de Tafrogêneses no Estateriano (1.8 Ga) e Toniano (750 Ma) (Neves et al. 1996 e Neves 1999).

Arcos magmáticos plutônicos são normalmente estruturas regionais que possuem íntima relação com o retrabalhamento crustal e seu espessamento. Durante processos de acresção /colisão desenvolvem-se magmas devido anatexia da crosta inferior e manto superior. Este magmatismo pode evoluir segundo três tipos de modelos tectônicos: underplating, detachment ou subducção. $\mathrm{O}$ tipo ou estágio geotectônico em que o arco se desenvolverá além dos protólitos envolvidos controlará sua assinatura química e isotópica.

\section{Litoestratigrafia}

COMPLEXO PAU DOS FERROS (CPF) Este complexo é formado por ortognaisses interdigitados, bandados e migmatizados, possui composição granítica a granodiorítica e megaenclaves dioríticos. Este complexo estudado por Sá et al. (1981) é correlato a outros complexos Paleoproterozóicos descritos nas regiões de Pau dos Ferros, Caicó, São Vicente e Açu (Hackspacher et al. 1992, Dantas 1992, Schmus et al. 1995, Magini 2001) e comporta-se como encaixante das rochas vulcanosedimentares estaterianas e graníticas edicarianas

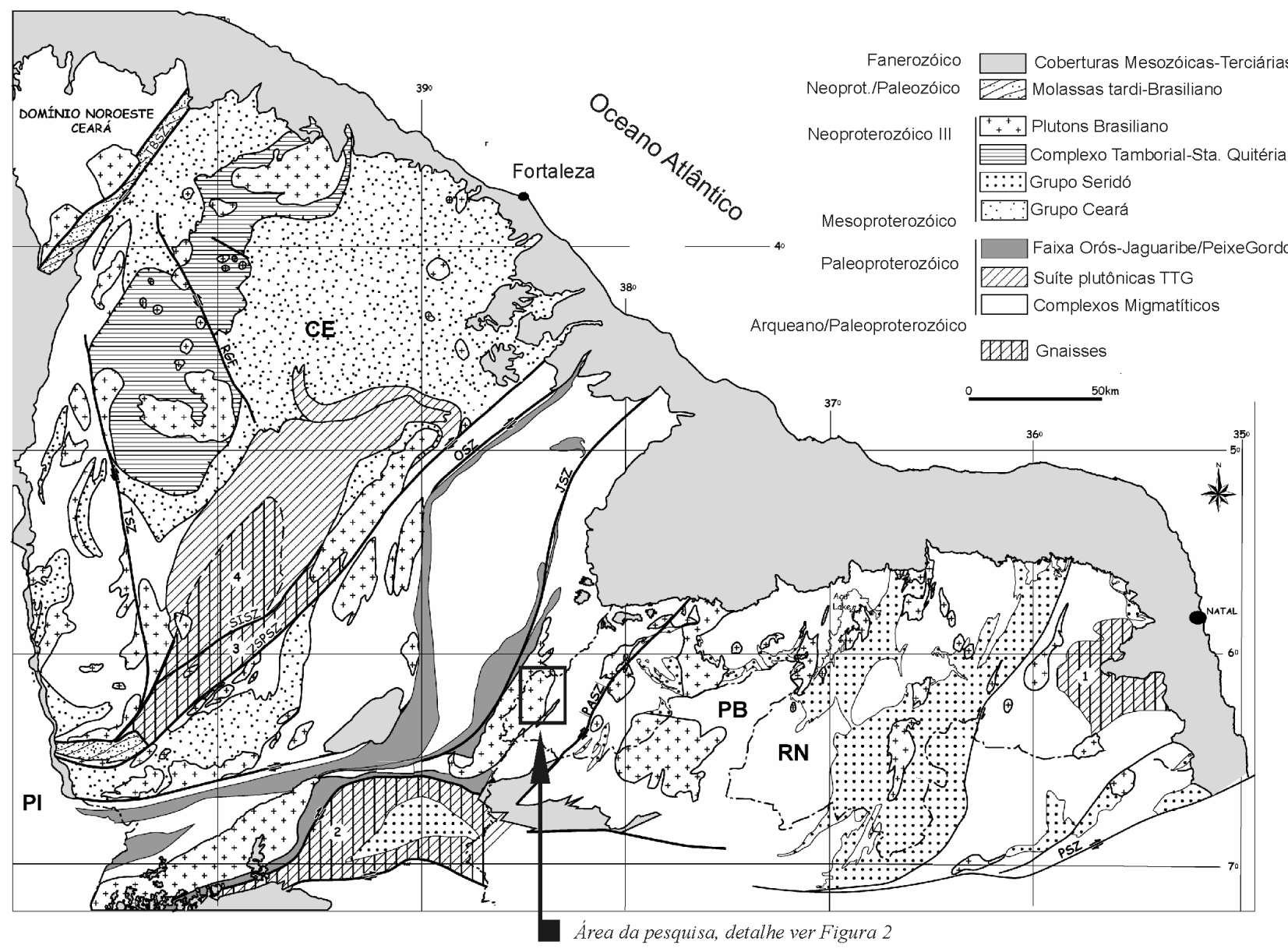

Figura 1 - Localização da área de pesquisa na setentrional da Pronvíncia Borborema (Norte do Lineamento de Patos), in Arthaud \& Fuck, 2007.OSZ (Zona de cisalhamento de Oró), JSC (Zona de Cisalhamento Jaguaribe), PASC (Zona de Cisalhamento Porto Alegre). 
Ortognaisses graníticos a granodioríticos (Ogg) Os ortognaisses graníticos a granodioríticos afloram na porção leste da área, exibem feições magmáticas interdigitadas com megaenclaves de dioritos. Quando deformados formam gnaisses bandados e gnaisses migmatíticos. Os Ogg apresentam texturas e estruturas ígneas como: fenocristais, enclaves sub-angulosos a arredondados, bandamento magmático, contatos serrilhados entre feldspatos, localmente com assimilação entre magmas, mistura parcial de magmas do tipo mixing e migling e fenocristais de feldspatos intercrescidos (K-feldspatos e Plagioclásios). A composição mineralógica, segundo análise modal é formada por: K-feldspatos (23\%), Plagioclásio (15\%), Quartzo (25\%), Anfibólio (8\%), Opacos (6\%), Biotita (1-3\%) e minerais acessórios como, Titanita, Epidoto, Allanita, Apatita, Muscovita.

Ortognaisses graniticos $(\mathrm{Og}) \quad$ Os ortognaisses graníticos ocorrem na porção centro-norte (Fig. 2A), são corpos ovalados e alongados na direção N-S. Os Og compõem a porção mais granítica do embasamento sendo formados por duas fácie: uma porfiróide com grande quantidade de porfiroblastos formando textura tipo augen, e outra fácie com textura homogênea de granulometria grossa. A mineralogia dos ortognaisses tipo augen segundo análise modal é formada por: Quartzo (30\%), K-feldspatos (35\%), Plagioclásios (28\%), Opa$\cos (3 \%)$ e minerais acessórios como Biotita, Hornblenda, Epidoto, Titanita e Opacos. O Og homogêneo possui textura granoblástica fina, segundo análise modal são compostos por: K-feldspato (35\%), Quartzo (25\%), Plagioclásios (10\%), Biotitas (4\%), Muscovita (2\%), Epidoto (3\%), Opacos (5\%), Apatita (3\%). Os poucos fenocristais são predominantemente formados por Ortoclásio e secundariamente por Microclinas.

Ortognaisses dioriticos (Odr) Os ortognaisses dioríticos ocorrem como mega-enclaves nos Ogg, são subangulares, apresentam contatos bruscos à serrilhados e localmente estruturas em cuspide. Quando deformados compõem as bandas mesocráticas nos gnaisses bandados, as quais passam a ter composição anfibolítica. Texturalmente os anfibólios e plagioclásios apresentam-se recristalizados e orientados nos planos da foliação subhorizontal mostrando que o metamorfismo Trasamazônico atingiu condições do facies anfibolito superior, onde o aparecimento de fundido ocorre por volta de 650 graus devido a presença de água no sistema biotita + hornblenda. A composição mineralógica segundo análise modal é formada por Hornblenda (30\%), Plagioclásio (45\%), Quartzo intergranular (4\%), Biotitas (10\%), Titanitas, Epidoto, Opacos (5\%) e Apatitas (2\%).

GRUPO SÃO JOSÉ (GSJ) O GSJ é formado por rochas de idade Estateriana (Magini 2001) ocorrem na porção central da área (Fig. 2A) e são correlatas as seqüências descritas por Sá (1991) e Figueiredo (1994) na região de Orós e Jaguaribe (CE) e da Seqüência Peixe Gordo na região de Tabuleiro do Norte $(\mathrm{RN})$ descritas por Cavalcante \& Sá (1997). Este processo também foi evidenciado em outras áreas do Brasil, formando sequências vulcano-sedimentares (Cavalcante \& Sá 1997, Neves et al. 1998, Magini et al. 1999). O GSJ juntamente com o CPF são as principais áreas fontes (protólitos) que podem ter contribuido para geração de magmas Edicarianos. Espera-se que os valores de $\mathrm{T}_{\mathrm{DM}}$ entre $2.5 \mathrm{Ga}$ até $1.8 \mathrm{Ga}$ estejam presentes nas rochas graníticas analisadas no AMP.

ARCO MAGMÁTICO DE PEREIRO (AMP) O Arco Magmático de Pereiro é formado por duas suítes: São Miguel e Dr. Severiano. Tais suítes possuem corpos de dimensões variadas possuindo caráter de plutons e batólitos. Esta variação na dimensão dos corpos juntamente com sua variação litológica e seu invariável alinhamento na direção N-S, NE-SW, além do seu caráter intrusivo nos sugere denominar de Arco Magmático de Pereiro os litotipos a seguir descritos.

Suite São Miguel (SSM) É composta por diversos corpos graníticos com dimensão de dezenas até centenas de quilometros quadrados, portanto variando "stricto sensu" entre Plutons e Batólitos. Tais corpos foram aqui denominados de: Batólito São Miguel/Pereiro (Monzogranitos), Batólito Luis Gomes (Monzogranito-Granito), Pluton Marcelino Vieira (Granito), Pluton Panatis (Monzogranito), Pluton Padre Cosme (Alcaligranito) e Leucrogranito Castelo.

Batólito São Miguel/Pereiro Esta unidade litoestratigráfica ocorre na parte oeste na forma de um grande corpo de $800 \mathrm{Km}^{2}$, sua composição varia de monzogranítica a quartzo monzonítica. A composição mineralógica é constituída por fenocristais de k-feldspatos e plagioclásios em meio a uma matriz rica em quartzo, feldspatos, opacos, hornblendas, biotitas e acessórios como apatita, titanita, epidoto, allanitas, granada. Ocorrem ainda inúmeros enclaves de dioritos e hornblenditos com morfologia circular ou alongados na direção NE-SW, de dimensões quilométricas. Os enclaves possuem a mesma composição que os dioritos da Suíte Dr. Severiano, sendo portanto uma fração de magma básico no pluton São Miguel/Pereiro. Apresentam-se truncando a foliação existente nas rochas da SSM e sua foliação interna é praticamente inexistente.

Pluton Alkali-granito Padre Cosme Este pluton ocorre na porção central abrangendo uma área de aproximadamente $80 \mathrm{Km}^{2}$, possui formato ovalado com eixo maior orientado na direção NE-SW. Na parte interna do pluton, onde a deformação foi menos intensa, observa-se textura homogênea e granulação média a grossa com fenocristais de feldspatos e ribbons de quartzo. Na borda do pluton a deformação provoca intensa milonitização, causando enriquecimento de muscovitas e quartzo. Mineralogicamente é composto por k-feldspato, quartzo, muscovita, opacos, plagioclásio, mica branca, titanita e acessórios como apatita, hornblenda, epidoto, biotita. 


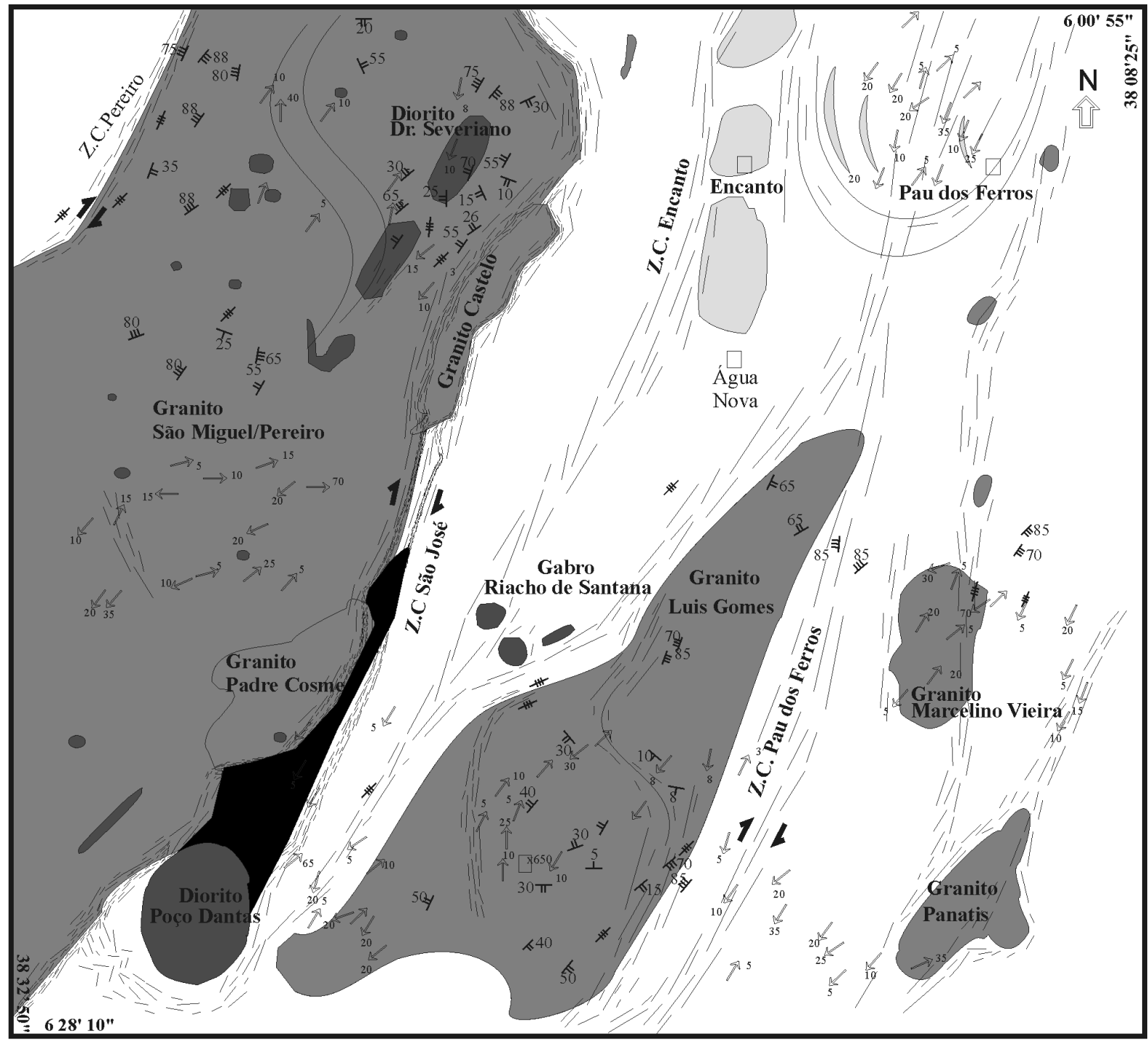

LEGENDA

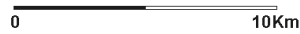

Arco Magmático de Pereiro

Grupo São José

Complexo Pau dos Ferros

Suíte São Miguel Suíte Dr. Severiano

Edicariano

Estateriano

Ortognaisses graníticos Ortognaisses graníticos a granodioríticos

Paleoproterozóico Inferior

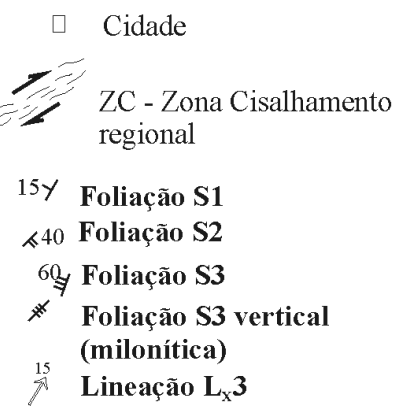

A
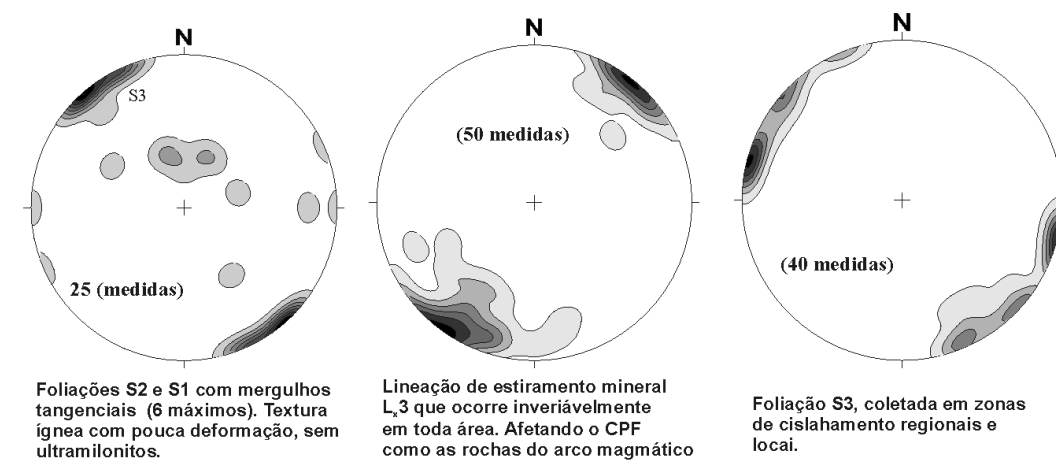

Foliação S3, coletada em zonas de cislahamento regionais $\mathrm{e}$

Estereogramas dos elementos estruturais (foliações, S1, S2, S3 e lineações $L_{x} 3$ ) gerados no neoproterozóicos. Medidas obtidas em plutons graniticos do arco

B

Figura 2 - (A) Mapa Geológico da Arco Magmático de Pereiro, (B) Estereogramas dos elementos estruturais S1, S2, S3, L3 na área pesquisada. 
Leucogranito Castelo A principal ocorrência desta rocha situa-se na Serra do Castelo, apresenta-se como um corpo alongado (12 Km, comprimento) na direção NE. Outros corpos de leucogranitos de menor dimensão ocorrem dispersos na área sob a forma de lentes decimétricas.

O Leucogranito Castelo é composto mineralogicamente por $\mathrm{k}$-feldspatos $(35 \%)$, quartzo $(30 \%)$, muscovita (15\%), plagioclásios $(5 \%)$, opacos $(3 \%)$ e acessórios como hornblenda, epidotos, titanita e apatita. Quando mais intensamente deformados os milonitos resultantes são enriquecidoso em muscovitas, opacos e nódulos de quartzo centimétricos.

Batólito de Luis Gomes Ocorre na porção centro-sul da área (Fig. 2A), possui aproximadamente $200 \mathrm{Km}^{2} \mathrm{e}$ forma sigmóidal orientado na direção NE-SW. É composto por dois litotipos: um mesocrático de textura homogênea e granulometria média a fina, composta de anfibólio (5\%), plagioclásios (15\%), k-feldspatos $(25 \%)$, biotita $(10 \%)$ e quartzo $(15 \%)$, formando um fácie granodiorítico; outro leucocrático com biotitas, anfibólios, fenocristais de k-feldspatos, injeções de quartzo e pegmatitos tardios, formando um fácie granítico. Em locais pouco deformados é possível observar estruturas como enclaves sub-angulares onde a facies leucocrática apresenta-se como tardia cortando os enclaves mesocráticos. Nas bordas do batólito ou em zonas de cisalhamento métricas na parte interna do mesmo, as duas facies se misturam formando um gnaisse bandado e gnaisse migmatítico.

Pluton Marcelino Vieira Este pluton de aproximadamente $10 \mathrm{Km}^{2}$ ocorre a NW da cidade homonima. Trata-se de um granito fino equigranular de coloração cinza, localmente variando para uma textura granoblástica média a grossa, possui diques e lentes decimétricas de pegmatitos. $\mathrm{O}$ caráter intrusivo é evidenciado pela foliação discordante da foliação das encaixantes, presença de xenólitos centimétricos a métricos angulosos e gnaissificados dos ortognaisses do CPF. É composto mineralogicamente por: $\mathrm{k}$-feldspatos $(30 \%)$, quartzo $(30 \%)$, plagioclásios $(20 \%)$, opacos $(4 \%)$ e acessórios $(16 \%)$ como biotita, titanita, apatita, muscovita, allanita, epidoto e hornblenda.

Pluton Panatis O Pluton Panatis ocorre na porção SE, possui morfologia alongada na direção NE-SW com aproximadamente $30 \mathrm{Km}^{2}$. Os limites entre o pluton e os ortognaisses do embasamento são marcados por zonas de cisalhamentos, onde são exploradas pedras semi-preciosas a preciosas como ametista e água-marinha. Petrograficamente apresenta textura porfirítica; os fenocristais $(1-5 \mathrm{~cm})$ são de $\mathrm{k}$-feldspatos, e compõem $60 \%$ do volume total da rocha, são envoltos por uma matriz de plagioclásio, quartzo, biotita, opacos, apatita, titanita, zircão, allanitas. Apresenta estrutura primária como entelhamento de fenocristais com sentido destral e intercrescimento entre as fases feldspáticas, formando estrutura em cunha e interdigitações com facies graní- tica fina. Também ocorrem diques tardios de granitos equigranulares finos e diques compostos (duas fases de injeção). A matriz apresenta-se foliada de forma incipiente com minerais recristalizados de K-feldspatos, os cristais de quartzo exibem extinção ondulante a mineralogia da matriz que compõe $40 \%$ do volume da rocha.

Suite Dr. Severiano (SDS) Essa suite representa o pulso básico e perfaz $20 \%$ do magmatismo do arco magmático, as rochas desta suíte foram denominadas de Dioritos Dr. Severiano, Gabros Riacho de Santana e Pluton Poço Dantas,

Dioritos Dr. Severiano Três tipos de dioritos foram identificados: dioritos equigranulares finos, equigranulares grosseiros e cumuláticos. Associados aos dioritos ocorrem localmente granito cinza fino equigranulare na forma de diques sin-plutônicos e na forma de autólitos centimétricos.

A facies equigranular fina ocorre na cidade de Dr. Severiano e como enclaves métricos inseridos no batólito São Miguel/Pereiro e no pluton Padre Cosme. Os enclaves são métricos e possuem formato de glóbulos, ocorrem disseminados em todo o batólito. Apenas nos arredores da cidade de Dr.Severiano ocorrem corpos de dimensões quilométricas, alongados na direção NE-SW que refratam a foliação regional do batólito São Miguel/Pereiro. Na parte sul da área os dioritos estão mais deformados formando corpos alongados, localmente anfibolitizados durante o metamorfismo Brasiliano. Mineralogicamente é formado plagioclásio $40 \%(\mathrm{An} \approx 60)$, hornblenda $(20 \%)$, biotita $(18 \%)$ titanita+ilmenita(5\%), clorita (acessório).

A facies equigranular grossa ocorre nos arredores da cidade de Dr. Severiano, apresenta foliação incipiente e uma grande quantidade de estruturas magmáticas como assimilação nas bordas entre as outras facies, mistura dos magmas dioríticos com magmas graníticos tardios, processos de biotitização formando nódulos, anfibolitização e concentração de minerais centimétricos formando localmente cumulatos. Os cumulatos são formados por biotitas + hornblendas $(90 \%$ da rocha) com estrutura maciça, localmente com foliação magmática devido a orientação de minerais euedrais que possuem ainda zoneamento intracristalino tipo coronado nos anfibólios.

A ocorrência do magmatismo diorítico se dá na forma de megaenclaves de diversas formas geométricas e diversos tipos de relações temporais. Estes megaenclaves são comuns em batólitos calcio-alcalinos e são relacionados a processos de diferenciação magmática (Müller et al. 1992). Estruturas semelhantes são decritas na Faixa Ribeira por Wernick (1999).

Gabro Riacho de Santana Ocorre na parte central da área, é caracterizado por gabros circulares e dimensões decamétricas. Os contatos litológicos estão encobertos ou encontram-se milonitizados nas bordas, paralelizando os gabros aos ortognaisses do CPF. Os gabros são compostos por fenocristais de plagioclásios (35\%), 
hornblendas (20\%) e biotitas (30\%), epidotos (acessório) possuem textura grossa e homogênea. Nas bordas dos corpos devido ao cisalhamento, a textura primária é substituída para uma textura milonítica ocorrendo localmente neocristalização de biotitas. As rochas milonitizadas estão orientadas na direção NE-SW e possuem foliação vertical e forte redução da granulometria primária durante a milonitização

Pluton Poço Dantas O Pluton Poço Dantas ocorre na porção SW, possui morfologia elíptica a ovalada e abrange uma área aproximada de $25 \mathrm{Km}^{2}$. Litologicamente é caracterizado por uma composição quartzomonzodiorítica com textura tipo augen. É composto por fenocristais de plagioclásio (55\%) e matriz grossa com hornblendas $(18 \%)$, biotitas $(20 \%)$, titanitas + opacos $(7 \%)$. Os anfibólios possuem zoneamento interno com bordas de reação e contatos intercrescidos com plagioclásios. Nas bordas do pluton também são encontrados veios centimétricos de calcita, aparentemente oriundos da perda de cálcio dos plagioclásios, migrando na forma de veios. $\mathrm{O}$ formato ovalado do pluton realça a refração da foliação das rochas encaixantes, formando localmente feições de ponto tríplice típicas de processos de colocação magmática tardi-tectônica (Hutton 1988). Na parte interna do pluton a foliação metamórfica acompanha o formato ovalado, com mergulho entre $55^{\circ}$ a $70^{\circ}$ para S-SW.

ARCABOUÇO ESTRUTURAL NEOPROTEROZÓICO A deformação neoproterozóica na área esta associada a Orogênese Brasiliana (600Ma). Esta deformação atingiu tanto as rochas do CPF reorientando foliações tangenciais existentes nos ortognaisses, como as rochas do Arco Magmático de Pereiro. A principal feição regional da área são plutons/batólitos limitados por zonas de cisalhamento regionais, identificadas aqui como: Zona de Cisalhamento de Pereiro, São José, Pau dos Ferros, Encanto (Fig. 2A).

No Arco Magmático de Pereiro a deformação varia conforme a seqüência de colocação, reologia da rocha e dimensão geométrica dos plutons, além de seu resfriamento no tempo geológico durante a orogênse em questão. Os incrementos deformacionais do neoproterozóico no arco foram sub-divididos segundo a interação de movimentos de colocação (foliação magmática + foliação tectônica) e deformação (foliação tectônica). Desta forma denominamos de incrementos D1 e D2, aos elementos estruturais gerados durante movimentos magmáticos e deformacionais e incrementos D3 puramente deformacionais.

Ocorreu ainda um evento tardio de caráter rúptil associado ao fraturamento dos granitos com injeções de pegmatitos em fraturas e falhas de pouco rejeito. Neste sentido abordaremos aspectos estruturais associados aos três incrementos deformacionais gerados no neoproterozóico (D1, D2 e D3).

Estruturas neoproterozóicas D1/S1 e D2/S2 As estruturas D1 e D2 foram identificadas nos batólitos de
São Miguel/Pereiro e Luis Gomes, no pluton Marcelino Vieira e no Leucogranito Castelo.

Os elementos estruturais deste incremento magmático/deformacional são caracterizados por planos $\mathrm{S} 1$ e S2 posicionados de forma tangencial (Fig. 2B). S1 apresenta-se como foliação magmática exibindo fenocristais e meio a uma matriz formada por minerais euedrais. S2 apresenta-se como uma foliação tectônica tangencial (mergulho com menos de 30 graus) paralela a $\mathrm{S} 1$, porém sua trama mineral mostra-se milonitizada.

No batólito São Miguel/Pereiro as foliações de baixo ângulo de mergulho (S1) são encontradas na parte interna, local onde a deformação é menos intensa, nestes locais identificou-se texturas magmáticas associadas a S1, como fenocristais deseorientados. Estes planos ocorrem paralelos aos planos S2 que estão associados a foliações predominantes de texturas granoblásticas até miloníticas. No Leucogranito Castelo (Serra do Castelo) os planos S1 e S2 que possuem o mesmo mecanismo de geração descrito no batólito São Miguel/Pereiro, formam foliações de baixo ângulo de mergulho com direção N-S e mergulhos para E e W variando de 5 a 35 graus.

Na parte sul do batólito de Luis Gomes os planos S1 e S2 formam uma seqüência de antiformes e sinformes com posterior verticalização para S3 no contato com os ortognaisses paleoproterozóicos. Nos arredores da cidade de Luis Gomes também ocorrem estruturas magmáticas associadas a foliação de baixo ângulo, localmente observamos entelhamento de feldspatos.

Estruturas neoproterozóicas D3/S3 As estruturas D3/S3 caracterizam-se por planos verticais a sub-verticais associados a uma lineação de estiramento mineral $\left(\mathrm{L}_{\mathrm{x}} 3\right)$ sub-horizontal em alguns locais paralelas a lineaçã̃o de eixo de dobras $\mathrm{L}_{\mathrm{B}} 3$, gerados em sistemas de trasncorrência. Os planos de foliação S3 (Zonas de Cisalhamento) são locais que permitem a colocação de magmas gerados durante o evento brasiliano, confirmando que a percolação de fundido. Esta fase de colocação D3 é o incremento final de grande deslocamento oriundo desde os movimentos tangenciais D1 e D2. A grande diferença é que a fase D3 permite não só a ascenção de fundido (fase transcorrente quente) más também exibe o fechamento termal inúmeros milonitos com foliação vertical de direção NE-SW, este final representa a fase transcorrente fria. A fase transcorrente fria de D3 nos Ogg e Og do embasamento formou zonas miloníticas do tipo L, ultramilonitos e localmente gnaisses migmatíticos a nebulíticos. A deformação D3 re-orientou os planos Sn, S1 e S2, além de gerar novos planos S3 de direção NE/verticail. No CPF a reorientação de dobras e planos tangenciais dos ortognaisses ocorrem em ângulos de 90 graus permitindo localmente a formação de padrões de interferência tipo boumerangue. $\mathrm{O}$ intenso estiramento mineral (Lineação, $\mathrm{L}_{\mathrm{x}} 3$ ) esta orientado na direção NE-SW e secundariamente N-S, ambas com mergulhos suaves 
com no máximo $10^{\circ}$ de caimento.

A deformação transcorrente (D3) no arco magmático de Pereiro forma preferencialmente zonas de cisalhamento destrais. Em campo as zonas de cisalhamento exibem nos perfis E-W (plano ZY), estruturas em flôr positiva e negativa e bandamento entre as litologias além de milonitos. Tais estruturas confirmam zonas de escape nos eixos $\mathrm{X}$ e $\mathrm{Y}$, formando elipsóides prolatos e oblatos em parte confirmados pela ocorrência de milonitos tipos $\mathrm{L}$ e tipo $\mathrm{S}$. Os milonitos tipo $\mathrm{L}$ são formados a partir de estiramento de fenocristais de feldspatos e anfibólios, ocorrem preferencialmente nos plutons porfiróides (batólitos São Miguel/Pereiro e Luis Gomes eDioritos Dr. Severiano). Os milonitos tipo $\mathrm{S}$ são formados pela neoformação sin-tectônica de muscovitas e biotitas.

Estruturas rúpteis neoproterozóicas A principal feição estrutural rúptil são fraturas extensionais preenchidas por pegmatitos de ordem métrica que ocorrem normalmente truncando as estruturas do CPF e do arco magmático de Pereiro Sistematicamente não apresentam foliação metamórfica e localmente podem exibir estruturas cataclásticas.

Um conjunto de diques de direção NE-SW são observados nos Dioritos Dr. Severiano, o fraturamento nos dioritos formou zonas extensivas que no modelo de Riedel caracterizam-se pelas fraturas R e T. A direção destas fraturas é N-S. No modelo de Ramsay \& Huber $(1987 a, b)$ a colocação dos pegmatitos ocorreu nas fraturas extensivas do Tipo $\mathrm{X}$.

No pluton Marcelino Vieira ocorrem diques na direção N-S com caimento para W de 45 graus. Estas fraturas são paralelas a foliação encontrada no granito, confirmando que as fraturas extensionais se formaram na mesma orientação da foliação $\mathrm{S} 3$, interpretadas como abertura dos planos $\mathrm{C}$ das zonas de cisalhamento destrais. Os diques são de ordem métrica a decimétrica e ocorrem com gemas (água marinha, ametista e topázio) na região de Tenente Ananias.

GEOQUÍMICA Todos os plutons foram analisados (Magini 2001) e sub-divididos nas Suíte São Miguel: Batólito São Miguel/Pereiro, Pluton Padre Cosme, Leucogranito Castelo, Batólito Luis Gomes, Pluton Panatis, Pluton Marcelino Vieira; e na Suíte Dr. Severiano: Dioritos Dr. Severiano, Pluton Poço Dantas e os Gabros Riacho de Santana. Os objetivos da geoquímica é caracterizar grupos co-genéticos, suas linearidades e definir séries magmáticas, classificação das rochas quanto a geoquímica, tectônica e padrões dos ETR. De posse destas análises modelar a evolução do arco magmático de Pereiro juntamente com os dados estruturais e geocronológicos.

Diagramas Harker's Os diagramas Harker's visam caracterizar trend's entre grupo de amostras cogenéticas permitindo evidenciar a presença dos pulsos magmáticos ou séries magmáticas ou mesmo anomalias.

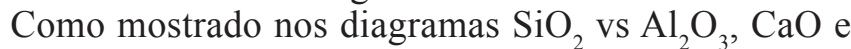

$\mathrm{Fe}_{2} \mathrm{O}_{3}$ (Fig. 3, Tab. 1) as correlações geoquímicas são negativas formando trend's lineares. No diagrama $\mathrm{SiO}_{2}$ vs $\mathrm{Na}_{2} \mathrm{O}$ os pontos se separam em dois grupos e sugerem duas linhas evolutivas quase paralelas ao eixo X, sugerindo duas séries magmáticas. No diagrama $\mathrm{SiO}_{2}$ vs $\mathrm{K}_{2} \mathrm{O}$ a correlação é positiva para as rochas da suíte Sã̃o miguel e negativa para a suíte Dr. Severiano, isto mostra-se claro na ocorrência de minerais ricos em potássio como muscovita e k-feldpatos respectivamente no leucogranito Castelo e batólito granítico de Luis Gomes. Nos diagramas $\mathrm{SiO}_{2}$ vs $\mathrm{TiO}_{2}, \mathrm{MnO}$ e $\mathrm{P}_{2} \mathrm{O}_{5}$, neste último as curvas de correlação são negativas com distribuição dos pontos formando linhas evolutivas retilíneas paralelas a eixo $\mathrm{X}$, confirmando que variações de 0 a $1 \%$ ocorrem nas duas suítes do arco, sendo o fosfato observado na forma de apatitas em todas as rochas da área pesquisada. $\mathrm{O}$ padrão $\mathrm{SiO} 2$ vs $\mathrm{TiO}_{2}$ não evidencia a cristalizaram sob condições não tamponadas de oxigênio uma vez que sua curva não apresenta picos e sim uma reta única e decrescente conforme o acréscimo de sílica.

No diagrama $\mathrm{Na} 2 \mathrm{O}$ vs $\mathrm{SiO} 2$ as duas suítes são bens evidenciadas pelo agrupamentos de seus pontos, contudo dentro de cada nuvem de amostras podemos inferir sua evolução geoquímica. A nuvem de SSM apresenta com acréscimo de sílica e descrécimo de $\mathrm{Na}$ e conseqüentes mente acréscimo de $\mathrm{K} 2 \mathrm{O}$ é observada em campo e na petrografia que trata-se da fases mais ricas em anfibólios de outras mais ricas em k-feldspatos.

Nos digramas Harker's que correlacionam $\mathrm{SiO}_{2}$ vs elementos traços (Fig. 4) sugerem linhas evolutivas de correlação linear negativa os elementos $\mathrm{Ni}, \mathrm{Cr}, \mathrm{Zr}$, $\mathrm{Sr}$ e Y, com maior espalhamento para os pontos nos diagrama $\mathrm{SiO}_{2}$ vs $\mathrm{Sr}$ e Y. Nos diagramas $\mathrm{SiO}_{2}$ vs Rb, $\mathrm{Ba}$ e $\mathrm{Nb}$ o alinhamento dos sugerem correlações positivas. O Ba apresenta reta evolutiva sub-paralelas ao eixo $\mathrm{X}$, os valores máximos e mínimos variam entre 1000 e 3000 ppm nas duas suítes. As retas evolutivas de $\mathrm{Rb}$ vs $\mathrm{SiO}$ mostra um aumento de $\mathrm{Rb}$, este acréscimo é acompanhando do aumento na mineralogia principal no leocogranito Castelo e no batólito Luis Gomes em k-feldspato e muscovita.

$\mathrm{O} \mathrm{Cr}$ apresenta coerência pois esta em maior quantidade nos gabros (1000ppm) empobrecendo para os dioritos atingindo valores entre 0 a $100 \mathrm{ppm}$. Os grupos de amostras possuem gradientes no que tange a evolução estrutural em campo e as associações metamórficas e ígneas presentes nos afloramentos. A presença de duas suítes se confirma não só pelo espalhamentos e agrupamento dos valores entre grupo de amostras na geoquímica como também pela diferença entre comportamento estrutural. Devemos lembrar que a SSM foi descrita com presença de foliações de baixo ângulo de mergulho com texturas ígneas transicionando para texturas metamórfica. Já na SDS as estruturas frágeis são preponderantes acomodando até pegmatitos devido o fraturamento de dioritos. Com esta interpolação de geoquímica e estrutural é que posicionamos a SSM como pulso inicial e SDS pulso final. 

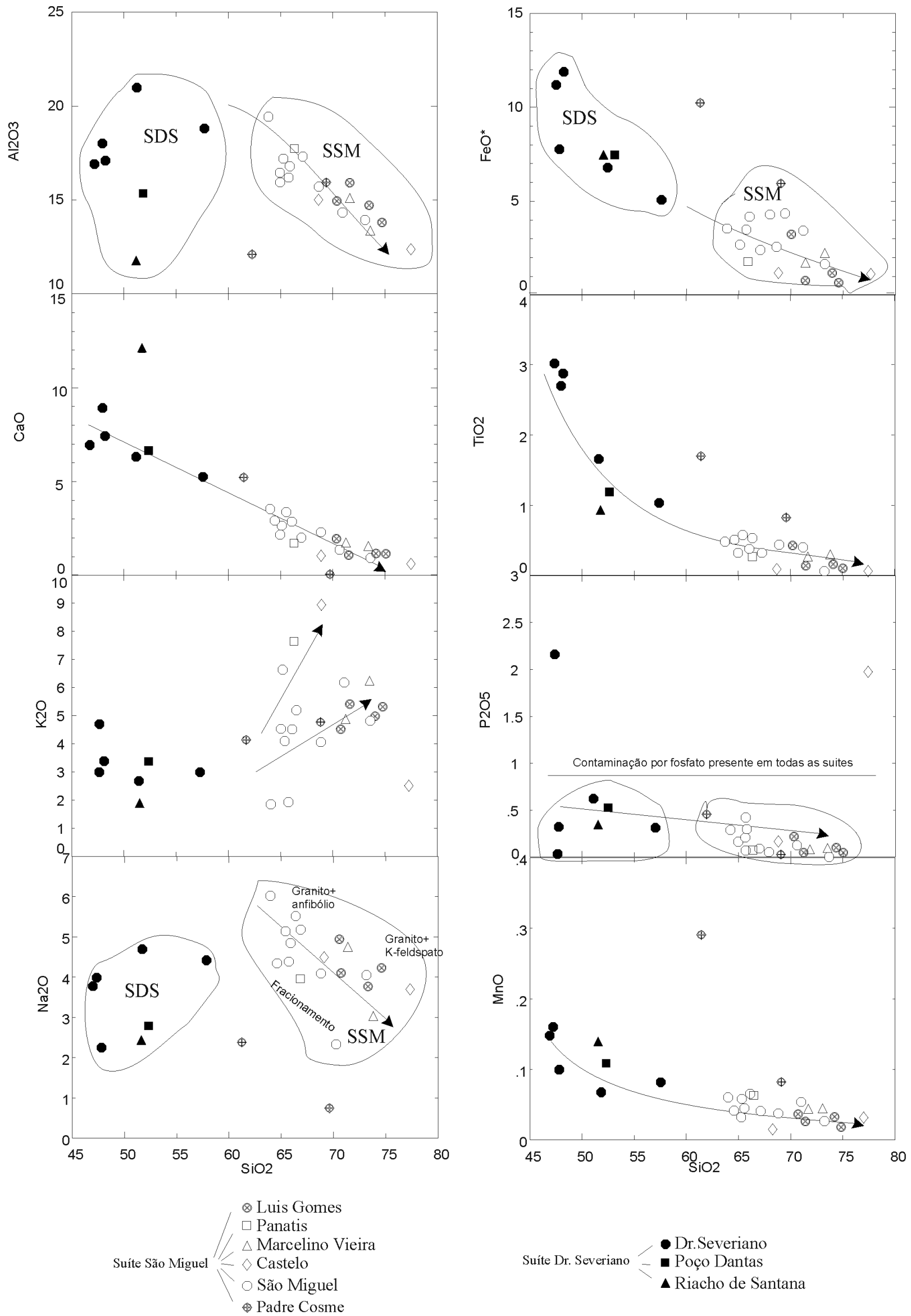

Figura 3 - Diagramas Harker's elementos maiores vs sílica para as rochas do Arco Magmático de Pereiro (AMP) divididas entre as Suite São Miguel, SSM e Suite Dr. Severiano, SDS.

OBS: $\mathrm{FeO} *$ ferro total 

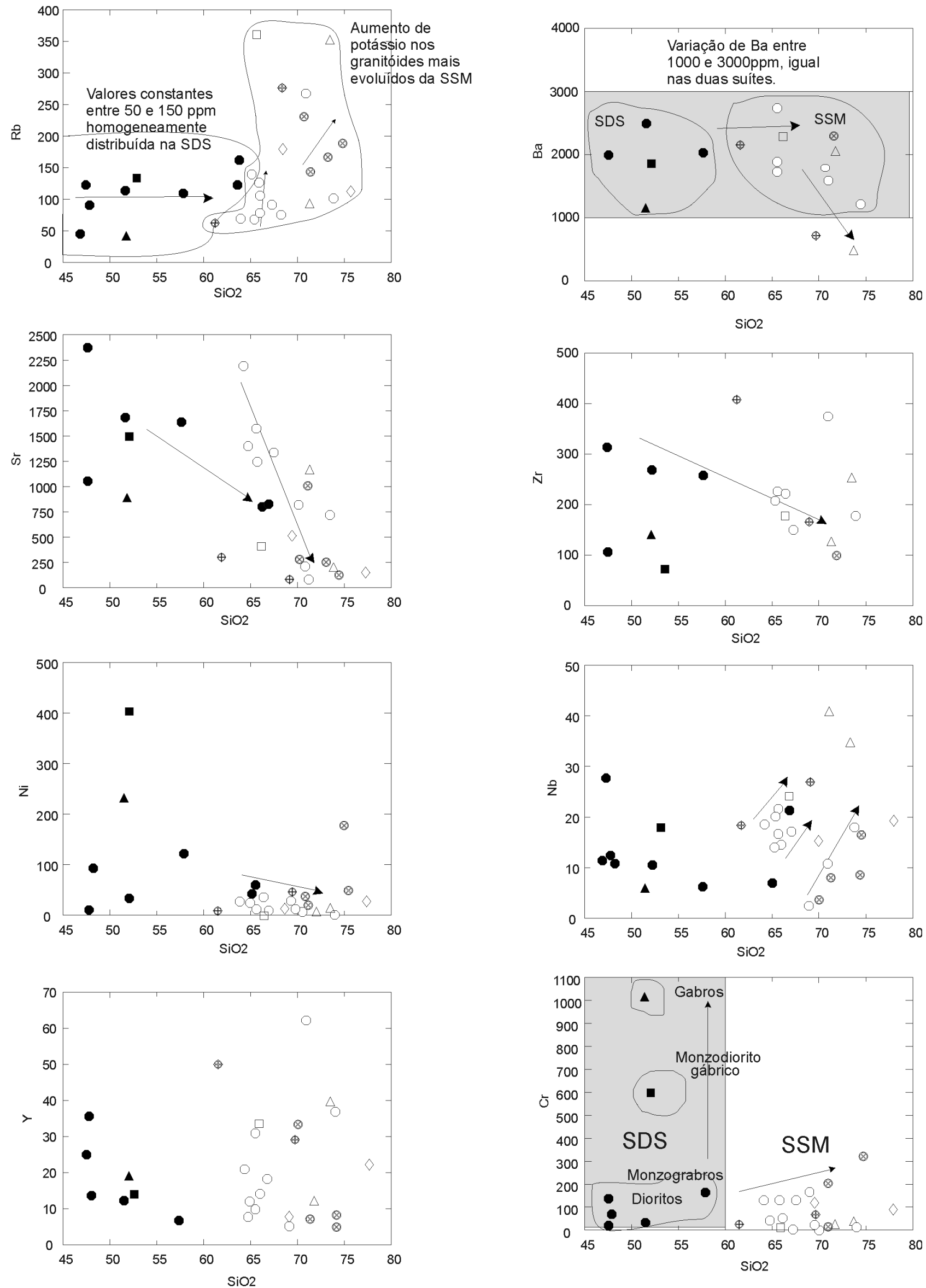

Figura 4 - Diagramas Harker's (traços) para as rochas do Arco Magmático de Pereiro (AMP) SSM - Suite São Miguel, SDS - Suite Dr. Severiano. 
Tabela 1 - Dados de Geoquímica total (elementos maiores, menores e traços e ETR) para as rochas do Arco Magmático de Pereiro - CE.

\begin{tabular}{|c|c|c|c|c|c|c|c|c|c|c|c|c|c|}
\hline & 1 & 2 & 3 & 4 & 5 & 6 & 7 & 8 & 9 & 10 & 11 & 12 & 13 \\
\hline $\mathrm{SiO} 2$ & 51.04 & 50.80 & 56.72 & 51.48 & 49.50 & 64.11 & 65.45 & 47.00 & 47.18 & 61.12 & 66.49 & 66.44 & 71.51 \\
\hline $\mathrm{TiO} 2$ & 1.00 & 1.11 & 0.97 & 1.61 & 2.66 & 0.55 & 0.56 & 3.03 & 2.76 & 1.70 & 0.81 & 0.31 & 0.20 \\
\hline $\mathrm{Al} 2 \mathrm{O} 3$ & 11.62 & 14.91 & 18.25 & 20.99 & 17.35 & 16.04 & 16.43 & 17.08 & 17.03 & 12.29 & 14.87 & 17.60 & 15.26 \\
\hline $\mathrm{Fe} 2 \mathrm{O} 3$ & 7.88 & 7.78 & 5.48 & 7.70 & 8.04 & 3.50 & 3.59 & 12.72 & 12.73 & 11.55 & 6.20 & 2.18 & 1.76 \\
\hline $\mathrm{MnO}$ & 0.14 & 0.10 & 0.08 & 0.07 & 0.09 & 0.05 & 0.06 & 0.15 & 0.16 & 0.29 & 0.08 & 0.06 & 0.04 \\
\hline $\mathrm{MgO}$ & 11.31 & 10.42 & 4.66 & 3.73 & 8.29 & 2.16 & 2.21 & 4.34 & 4.09 & 1.69 & 2.42 & 0.41 & 0.37 \\
\hline $\mathrm{CaO}$ & 12.15 & 6.47 & 5.11 & 6.45 & 8.73 & 2.86 & 2.92 & 7.04 & 7.18 & 4.91 & 0.19 & 1.66 & 1.66 \\
\hline $\mathrm{Na} 2 \mathrm{O}$ & 2.42 & 2.71 & 4.39 & 4.76 & 2.22 & 4.27 & 4.36 & 3.74 & 3.87 & 2.17 & 0.80 & 4.00 & 4.66 \\
\hline $\mathrm{K} 2 \mathrm{O}$ & 1.83 & 3.22 & 3.01 & 2.78 & 3.32 & 4.46 & 4.26 & 3.02 & 2.59 & 4.21 & 4.63 & 7.70 & 4.76 \\
\hline $\mathrm{P} 2 \mathrm{O} 5$ & 0.29 & 0.50 & 0.30 & 0.61 & 0.28 & 0.27 & 0.27 & 2.16 & 2.01 & 0.59 & 0.05 & 0.10 & 0.07 \\
\hline LOI & 1.17 & 1.05 & 0.65 & 0.72 & 1.64 & 0.28 & 0.42 & 0.58 & 0.74 & 0.47 & 1.86 & 0.40 & 0.14 \\
\hline Total & 100.86 & 99.06 & 99.62 & 100.91 & 98.51 & 98.54 & 100.54 & 100.91 & 100.34 & 100.97 & 98.39 & 100.86 & 100.43 \\
\hline $\mathrm{Ba}$ & 1086 & 1788 & 2021 & 2475 & 9882 & 1860 & 1900 & 1992 & & 2082 & 593 & 2294 & 2070 \\
\hline $\mathrm{Sr}$ & 854 & 1455 & 1632 & 1657 & 2335 & 996 & 1018 & 1032 & & 325 & 74 & 340 & 1094 \\
\hline $\mathrm{Y}$ & 18 & 14 & 7 & 14 & 13 & 9 & 9 & 35 & 25.7 & 49 & 28 & 33 & 12 \\
\hline $\mathrm{Zr}$ & 134 & 91 & 259 & 259 & 102 & 221 & 230 & 307 & & 406 & 160 & 178 & 123 \\
\hline $\mathrm{Be}$ & 2 & 2 & 2 & 2 & 2 & 3 & 3 & 2 & & 4 & 3 & 4 & 3 \\
\hline $\mathrm{V}$ & 196 & 113 & 88 & 91 & 279 & 43 & 42 & 134 & & 103 & 62 & 16 & 14 \\
\hline $\mathrm{Au} *$ & 24 & 53 & $<5$ & 13 & $<5$ & $<5$ & 10 & 11 & & 7 & 9 & $<5$ & $<5$ \\
\hline As & $<2$ & $<2$ & $<2$ & $<2$ & $<2$ & $<2$ & $<2$ & $<2$ & & $<2$ & $<2$ & $<2$ & $<2$ \\
\hline $\mathrm{Br}$ & $<1$ & $<1$ & $<1$ & $<1$ & $<1$ & $<1$ & $<1$ & $<1$ & & $<1$ & $<1$ & $<1$ & $<1$ \\
\hline Co & 39 & 45 & 25 & 27 & 48 & 9 & 10 & 43 & & 21 & 26 & 6 & 5 \\
\hline $\mathrm{Cr}$ & 1000 & 590 & 170 & 25 & 55 & 48 & 66 & 7 & & 7 & 67 & 7 & $<2$ \\
\hline Cs & 3.5 & 2.7 & $<0.5$ & 3.7 & $<0.5$ & 1.1 & $<0.5$ & $<0.5$ & & 1.6 & 43.7 & 5.0 & 0.6 \\
\hline $\mathrm{Hf}$ & 3.7 & 3.7 & 5.7 & 6.4 & 4.0 & 5.0 & 6.1 & 7.3 & & 9.6 & 4.6 & 5.1 & 3.7 \\
\hline $\mathrm{Hg}$ & $<1$ & $<1$ & $<1$ & $<1$ & $<1$ & $<1$ & $<1$ & $<1$ & & $<1$ & $<1$ & $<1$ & $<1$ \\
\hline Ir * & $<5$ & $<5$ & $<5$ & $<5$ & $<5$ & $<5$ & $<5$ & $<5$ & & $<5$ & $<5$ & $<5$ & $<5$ \\
\hline Mo & $<5$ & $<5$ & $<5$ & $<5$ & $<5$ & $<5$ & $<5$ & $<5$ & & $<5$ & $<5$ & $<5$ & $<5$ \\
\hline $\mathrm{Rb}$ & 40 & 133 & 101 & 112 & 86 & 100 & 134 & 119 & & 69 & 261 & 364 & 89 \\
\hline $\mathrm{Sb}$ & $<0.2$ & $<0.2$ & $<0.2$ & $<0.2$ & $<0.2$ & $<0.2$ & $<0.2$ & $<0.2$ & & $<0.2$ & 0.6 & $<0.2$ & $<0.2$ \\
\hline $\mathrm{Sc}$ & 53 & 19 & 15 & 16 & 26 & 4.9 & 6.0 & 12 & & 28 & 15 & 3.5 & 3.4 \\
\hline $\mathrm{Se}$ & $<3$ & $<3$ & $<3$ & $<3$ & $<3$ & $<3$ & $<3$ & $<3$ & & $<3$ & $<3$ & $<3$ & $<3$ \\
\hline $\mathrm{Ta}$ & $<1$ & $<1$ & $<1$ & $<1$ & $<1$ & $<1$ & $<1$ & 2 & & $<1$ & $<1$ & $<1$ & $<1$ \\
\hline Th & 1.4 & 2.3 & 3.5 & $<0.5$ & 0.8 & 4.4 & 4.7 & 2.2 & & 11 & 12 & 8.9 & 6.4 \\
\hline $\mathrm{U}$ & 0.9 & $<0.5$ & $<0.5$ & $<0.5$ & $<0.5$ & 1.3 & 1.3 & $<0.5$ & & 2.3 & 2.2 & 6.4 & $<0.5$ \\
\hline $\mathrm{W}$ & $<3$ & $<3$ & $<3$ & $<3$ & $<3$ & $<3$ & $<3$ & $<3$ & & $<3$ & 4 & $<3$ & $<3$ \\
\hline $\mathrm{La}$ & 27.9 & $\begin{array}{l}54.6 \\
\end{array}$ & $\begin{array}{l}68.2 \\
\end{array}$ & $\begin{array}{l}37.9 \\
\end{array}$ & 25.5 & $\begin{array}{l}41.9 \\
\end{array}$ & $\begin{array}{l}48.8 \\
\end{array}$ & 75 & 51.86 & 91.8 & 41.6 & 131 & 20.5 \\
\hline $\mathrm{Ce}$ & 54 & 93 & 107 & 75 & 51 & 73 & 78 & 148 & 118.81 & 166 & 82 & 131 & 36 \\
\hline $\mathrm{Nd}$ & 35 & 42 & 43 & 36 & 28 & 32 & 35 & 76 & 57.45 & 77 & 34 & 74 & 17 \\
\hline $\mathrm{Sm}$ & 5.4 & 6.2 & 4.9 & 5.9 & 5.3 & 4.4 & 4.3 & 13 & 11.46 & 13 & 5.8 & 9.8 & 2.4 \\
\hline $\mathrm{Eu}$ & 1.7 & 2.0 & 1.9 & $\begin{array}{l}1.9 \\
\end{array}$ & 2.0 & 1.4 & 1.4 & 4.1 & 2.82 & 2.6 & 1.0 & 2.2 & 0.7 \\
\hline $\mathrm{Tb}$ & $<0.5$ & $<0.5$ & $<0.5$ & $<0.5$ & $<0.5$ & $<0.5$ & $<0.5$ & 1.4 & & 1.4 & $<0.5$ & 1.1 & $<0.5$ \\
\hline $\mathrm{Cu}$ & 52 & 34 & 28 & 23 & 65 & 25 & 5 & 35 & & 25 & 2 & 2 & 2 \\
\hline $\mathrm{Pb}$ & $<5$ & 5 & 8 & 11 & $<5$ & 33 & 22 & $<5$ & & 56 & 19 & 59 & 48 \\
\hline $\mathrm{Zn}$ & 61 & 84 & 102 & 88 & 55 & 59 & 59 & 120 & & 190 & 64 & 42 & 45 \\
\hline $\mathrm{Ag}$ & $<0.4$ & $<0.4$ & $<0.4$ & $<0.4$ & $<0.4$ & $<0.4$ & $<0.4$ & $<0.4$ & & $<0.4$ & $<0.4$ & $<0.4$ & $<0.4$ \\
\hline $\mathrm{Ni}$ & 225 & 405 & 126 & 35 & 84 & 405 & 38 & 5 & & 3 & 43 & 2 & 3 \\
\hline $\mathrm{Cb}$ & 1.9 & 1.9 & 1.1 & 1.7 & 1.7 & 1.9 & 1.0 & 2.3 & & 1.7 & 1.0 & 0.7 & 0.5 \\
\hline $\mathrm{Bi}$ & $<5$ & $<5$ & $<5$ & $<5$ & $<5$ & $<5$ & $<5$ & $<5$ & & $<5$ & $<5$ & $<5$ & $<5$ \\
\hline $\mathrm{Yb}$ & 1.5 & 1.2 & 0.5 & 0.8 & 0.9 & 0.6 & 0.5 & 2.3 & 1.57 & 4.0 & 2.3 & 2.2 & 1.0 \\
\hline $\mathrm{Lu}$ & 0.22 & 0.14 & 0.08 & 0.12 & 0.11 & 0.08 & 0.09 & 0.35 & 0.26 & 0.60 & 0.37 & 0.33 & 0.16 \\
\hline $\mathrm{Nb}$ & 6 & 14 & 6 & 9 & & 12 & 8 & 26 & & 20 & 18 & 11 & 10 \\
\hline
\end{tabular}

Elementos traços e terras raras em ppm , Au * e Ir * em ppb , Elemento maiores e menores em \% 


\section{Tabela 1 - Continuação}

\begin{tabular}{|c|c|c|c|c|c|c|c|c|c|c|c|c|}
\hline & 14 & 15 & 16 & 17 & 18 & 19 & 20 & 21 & 22 & 23 & 24 & 25 \\
\hline $\mathrm{SiO} 2$ & 73.47 & 70.71 & 77.67 & 71.05 & 71.72 & 70.55 & 73.77 & 65.52 & 64.94 & 73.81 & 69.18 & 61.89 \\
\hline TiO2 & 0.21 & 0.10 & 0.08 & 0.11 & 0.06 & 0.41 & 0.10 & 0.27 & 0.38 & 0.14 & 0.43 & 0.44 \\
\hline $\mathrm{Al} 2 \mathrm{O} 3$ & 13.48 & 15.87 & 12.45 & 15.71 & 13.21 & 14.71 & 14.43 & 17.15 & 16.52 & 14.10 & 14.13 & 18.62 \\
\hline $\mathrm{Fe} 2 \mathrm{O} 3$ & 2.12 & 1.29 & 1.20 & 1.05 & 0.86 & 3.47 & 1.29 & 2.30 & 3.73 & 1.90 & 3.58 & 3.67 \\
\hline $\mathrm{MnO}$ & 0.04 & 0.01 & 0.02 & 0.03 & 0.02 & 0.04 & 0.03 & 0.04 & 0.06 & 0.03 & 0.05 & 0.06 \\
\hline $\mathrm{MgO}$ & 0.26 & 0.09 & 0.12 & 0.19 & 0.12 & 0.71 & 0.14 & 0.47 & 0.96 & 0.17 & 0.28 & 0.89 \\
\hline $\mathrm{CaO}$ & 1.22 & 0.61 & 0.56 & 1.18 & 1.09 & 1.75 & 1.13 & 2.00 & 2.96 & 1.21 & 1.73 & 3.44 \\
\hline $\mathrm{Na} 2 \mathrm{O}$ & 3.15 & 4.43 & 3.78 & 4.99 & 4.15 & 4.02 & 3.83 & 5.15 & 4.98 & 4.09 & 2.54 & 5.97 \\
\hline $\mathrm{K} 2 \mathrm{O}$ & 6.23 & 6.50 & 4.72 & 5.40 & 4.35 & 4.20 & 5.01 & 5.02 & 4.52 & 4.89 & 6.05 & 4.91 \\
\hline $\mathrm{P} 2 \mathrm{O} 5$ & 0.05 & 0.02 & 0.01 & 0.05 & 0.01 & 0.10 & 0.02 & 0.09 & 0.15 & 0.03 & 0.13 & 0.18 \\
\hline LOI & 0.28 & 0.19 & 0.13 & 0.12 & 0.24 & 0.30 & 0.30 & 0.26 & 0.22 & 0.23 & 0.30 & 0.38 \\
\hline Total & 100.52 & 99.81 & 100.73 & 99.88 & 95.82 & 100.26 & 100.05 & 98.27 & 99.41 & 100.58 & 98.39 & 100.45 \\
\hline $\mathrm{Ba}$ & 540 & & & 2227 & & & & 3248 & 2678 & 1273 & 1754 & \\
\hline $\mathrm{Sr}$ & 161 & & & 1014 & & & & 1314 & 1288 & 692 & 234 & \\
\hline $\mathrm{Y}$ & 39 & 7.77 & 22.0 & 7 & 4.49 & 32.29 & 6.88 & 18 & 31 & 38 & 61 & 20.5 \\
\hline $\mathrm{Zr}$ & 254 & & & 98 & & & & 145 & 221 & 184 & 378 & \\
\hline $\mathrm{Be}$ & 4 & & & 3 & & & & 4 & 2 & 2 & 7 & \\
\hline $\mathrm{V}$ & 8 & & & 9 & & & & 17 & 32 & 5 & 11 & \\
\hline $\mathrm{Au} *$ & $<5$ & & & 7 & & & & 14 & $<5$ & $<5$ & 8 & \\
\hline As & $<2$ & & & $<2$ & & & & $<2$ & $<2$ & $<2$ & $<2$ & \\
\hline $\mathrm{Br}$ & $<1$ & & & $<1$ & & & & $<1$ & $<1$ & $<1$ & $<1$ & \\
\hline Co & 4 & & & $<1$ & & & & 4 & 7 & 3 & 5 & \\
\hline $\mathrm{Cr}$ & 14 & & & 5 & & & & 11 & 22 & 3 & $<2$ & \\
\hline $\mathrm{Cs}$ & 3.1 & & & 1.1 & & & & $<0.5$ & 1.6 & 1.5 & 2.1 & \\
\hline $\mathrm{Hf}$ & 7.0 & & & 2.9 & & & & 4.0 & 5.8 & 5.9 & 12 & \\
\hline $\mathrm{Hg}$ & $<1$ & & & $<1$ & & & & $<1$ & $<1$ & $<1$ & $<1$ & \\
\hline Ir * & $<5$ & & & $<5$ & & & & $<5$ & $<5$ & $<5$ & $<5$ & \\
\hline Mo & $<5$ & & & $<5$ & & & & $<5$ & $<5$ & $<5$ & $<5$ & \\
\hline $\mathrm{Rb}$ & 348 & & & 139 & & & & 98 & 129 & 105 & 263 & \\
\hline $\mathrm{Sb}$ & $<0.2$ & & & $<0.2$ & & & & $<0.2$ & $<0.2$ & $<0.2$ & 0.2 & \\
\hline $\mathrm{Sc}$ & 4.0 & & & 4.1 & & & & 4.5 & 6.4 & 3.4 & 7.4 & \\
\hline $\mathrm{Se}$ & $<3$ & & & $<3$ & & & & $<3$ & $<3$ & $<3$ & $<3$ & \\
\hline $\mathrm{Ta}$ & $<1$ & & & $<1$ & & & & $<1$ & 4 & 3 & 3 & \\
\hline Th & 57 & & & 2.4 & & & & 2.4 & 6.0 & 21 & 18 & \\
\hline $\mathrm{U}$ & 5.0 & & & 0.9 & & & & $<0.5$ & $<0.5$ & 3.8 & 2.8 & \\
\hline W & $<3$ & & & $<3$ & & & & $<3$ & $<3$ & $<3$ & $<3$ & \\
\hline $\mathrm{La}$ & 122 & 15.77 & 13.40 & 7.8 & 4.59 & 148.19 & 2.98 & 18.1 & 46.0 & 53.9 & 122 & 39.63 \\
\hline $\mathrm{Ce}$ & 209 & 31.54 & 33.89 & 13 & 8.99 & 323.71 & 48.81 & 33 & 64 & 84 & 228 & 71.76 \\
\hline $\mathrm{Nd}$ & 72 & 10.17 & 15.56 & 8 & 4.35 & 91.68 & 14.56 & 15 & 29 & 37 & 90 & 36.05 \\
\hline $\mathrm{Sm}$ & 11 & 2.17 & $\begin{array}{l}4.38 \\
\end{array}$ & 1.2 & 1.06 & 15.01 & 3.13 & 3.1 & 4.8 & 6.5 & 15 & 36.05 \\
\hline $\mathrm{Eu}$ & 1.1 & 0.60 & 0.48 & 0.5 & 0.55 & 2.05 & 0.68 & 0.8 & 1.6 & 1.0 & 2.4 & 1.66 \\
\hline $\mathrm{Tb}$ & 1.4 & & & $<0.5$ & & & & $<0.5$ & 1.2 & 1.4 & 1.9 & \\
\hline $\mathrm{Cu}$ & 2 & & & 2 & & & & 2 & 2 & 21 & 7 & \\
\hline $\mathrm{Pb}$ & 50 & & & 45 & & & & 47 & 27 & 159 & 33 & \\
\hline $\mathrm{Zn}$ & 47 & & & 25 & & & & 55 & 65 & 19 & 64 & \\
\hline $\mathrm{Ag}$ & $<0.4$ & & & $<0.4$ & & & & $<0.4$ & $<0.4$ & $<0.4$ & $<0.4$ & \\
\hline $\mathrm{Ni}$ & 4 & & & 3 & & & & 6 & 10 & 2 & 2 & \\
\hline $\mathrm{Cb}$ & $<0.5$ & & & $<0.5$ & & & & 0.7 & $<0.5$ & 0.5 & 0.8 & \\
\hline $\mathrm{Bi}$ & $<5$ & & & $<5$ & & & & $<5$ & $<5$ & $<5$ & $<5$ & \\
\hline $\mathrm{Yb}$ & 3.2 & 0.76 & 1.79 & 0.6 & 0.32 & 1.85 & 0.65 & 1.6 & 1.8 & 3.5 & 5.3 & 1.40 \\
\hline $\mathrm{Lu}$ & 48 & 0.12 & 0.24 & 0.11 & 0.06 & 0.30 & 0.12 & 0.22 & 0.29 & 0.51 & 0.74 & 0.20 \\
\hline $\mathrm{Nb}$ & 24 & & & 8 & & & & 22 & 17 & 15 & 23 & \\
\hline
\end{tabular}


Diagramas classificatórios No diagrama QAP (Fig. 5) os granitóides variam de dioritos/gabros, qz-dioritos, monzodioritos, monzonitos, qz-monzodioritos, qz-monzonitos, tonalitos, granodioritos, granitos e sienitos. No diagrama TAS a SSM variam de granitos, monzogranitos e granodioritos já a SDS possui maior variações ocorrem desde gabros, mozodioritos gábricos, monzogábros a dioritos. No diagrama que classifica quanto a alkalinidade mostra que os granitóides da SSM apresentam característica sub-alcalina.já os granitóides da SDS alkalina. Tanto na SSM como na SDS os valores de potássio variam de alto-K a médio-K predomimam rochas de características shoshoníticas, em parte com traços de material mantélico. Os granitóides leucocráticos são sub-alkalinos (Irvine \& Baragard 1971), contudo no diagrama de Peecock a relação silica vs álcalis mostra características alcali-cálcica. No diagrama ternário AFM os granitóides são tipicamente cálcio-alcalinos. Todos os granitóides possuem marcante enriquecimento em $\mathrm{Ba}$ e potássio, sendo predominantemente potássicas segundo $\mathrm{Na}_{2} \mathrm{O}$ vs $\mathrm{K}_{2} \mathrm{O}$. Os altos valores de potássio são reflexo de uma mineralogia que predomina o K-feldspato sobre o plagioclásio, confirmação esta avaliada na petrografia das rochas do arco de Pereiro.

Os maioria das rochas da Suíte Dr. Severiano (Dioritos, Dioritos porfiróides e Gabros) apresentam característica alcalina de alto potássio. No diagrama $\mathrm{SiO} 2$ vs K2O apresentam características ultrapotássicas a shoshoníticas. As rochas básicas do complexo granitóides são enrriquecidas em $\mathrm{MgO}$ e em bário (Fig. 5). A Suíte Dr.Severiano segundo a relação $\mathrm{Al}_{2} \mathrm{O}_{3}$ vs $\mathrm{MgO}$ possui característica de rochas Apeníticas, onde o teor de $\mathrm{MgO}$ (> 4\%) é elevado em relação ao alumínio, padrões similares foram descritos por Pitcher (1975). Além da similaridade geoquímica o autor também descreve que temporalmente o magmatismo básico comporta-se como o pulso final do plutonismo, podendo ser correlacionável a produção de restitos formados por fusão parcial durante retrabalhamento de material crustal misturado com frações mantélicas, gerando magmas híbridos devido a processos metassomáticos do manto litosférico superior e base da crosta. Como o magma da SDS é tardio ao magma da SSM o mesmo trunca as estruturas S1 e S2 inúmeras vezes. Sua colocação esta posicionada como sin a tardi transcorrências S3.

Os padrões shonshonítcos corroboram para interpretar na existência de contaminação do manto na geração do arco magmático de Pereiro.

Diagramas de classificação serial e fracionamento mineral $\mathrm{O}$ fracionamento mineral a partir do diagrama de Shand, mostra para os granitóides leuco a mesocráticos uma distribuição dos pontos acompanhando a reta do piroxênio, anfibólio, para os dioritos o fracionamento acompanha a reta do plagioclásio (Fig. 6). Não foram observados piroxênio nas rochas do arco sendo atribuído o fracionamento apenas ao anfibólio.

Quanto ao índice de alumina a SSM varia de peraluminosa, metaluminosa, já a SDS é metaluminosa (Maniar \& Piccoli 1989) revelando contribuição de protólitos de crosta continental na geração dos magmas.
Na relação $\mathrm{SiO}_{2}$ vs Sc foi possível detectar o fracionamento do anfibólio onde os pontos alinham-se formando uma reta de correlação negativa conforme o incremento de silica. Vale salientar que as rochas básicas são tardias em relação as rochas ácidas, permitinda traçar um trend inverso em relação ao aumento de sílica. No diagrama $\mathrm{La} / \mathrm{Yb}$ vs La foi possível definir dois grupos de amostras, confirmando a existência de duas suítes magmáticas. As suítes não apresentam fracionamento de minerais acessórios segundo parâmetros de $\mathrm{SiO}_{2}$ vs REE (Fig. 6) porém o pluton Panatis apresenta ocorrências de gemas como ametista e berilo. Isto permite definir como sendo o granito mais evoluído do arco magmático de Pereiro.

Nos granitóides que possuem texturas porfiróides com fenocristais de plagioclásio, foi possível rastrear o comportamento desses minerais, através da anomalia negativa de Eu (batólito São Miguel/Pereiro, batólito Luis Gomes, Leucogranito Castelo e pluton Marcelino Vieira). Foram observadas duas anomalias positivas de Eu no batólito Luis Gomes indicando a ocorrência de cumulatos de feldspatos e diversas anomalias negativas de Eu, confirmando o fracionamento deste mineral. Nos diagramas bi-log $\mathrm{Sr}, \mathrm{Ba}, \mathrm{Rb}$ os pontos se alinham formando retas predominantemente paralelas ao fracionamento do k-feldspato e hornblenda e secundariamente retas paralelas ao fracionamento do plagioclásio.

$\mathrm{O}$ fracionamento nos magmas básicos (Suíte Dr. Severiano) neste caso é grande parte controlado por plagioclásios e hornblendas. Já o fracionamento nos magmas ácidos (Suíte São Miguel) aparentemente foi controlado pelo k-feldspato. Na petrografia esta relação é confirmada pela presença de microtexturas de intercrescimento entre plagioclásios, hornblendas, k-feldspatos, biotita e acessórios.

Foram identificadas anomalias de fosfato tanto nos granitóides neoproterozóicos quanto nos ortognaisses paleoproterozóicos. Este aspecto em lâmina correlacionase a alta percentagem de apatita tardia (cristalização em fraturas ou mesmo na foliação). Este aspecto mineral/geoquímico ocorre em toda a área aparentemente controlado pelas características geoquímicas da crosta retrabalhada. Este retrabalhamento envolve as rochas do CPF e GSJ, este último com sedimentação marinha permitindo durante a fusão crustal a contaminação por fosfato a partir de sedimentos químicos de idade Estateriana provenientes das paleobacias de São José ou mesmo de Orós/Jaguaribe (Magini 2001, Sá 1991 e Figueiredo 1994).

Pulsos magmáticos, classificação tectônica e ETR A relação Rb vs Sr (Bi-log) e Rb vs K/1000 procura delinear os pulsos magmáticos que ocorreram na formação do arco magmático já observada em gráficos anteriores e nas relações de campo. Segundo a distribuição das amostras é possível correlacionar com dois pulsos, entre as razões 100-200 e 300-500. Os pulsos magmáticos estão direta ou indiretamente relacionadas a rochas de alto-K associadas a processos de subducção de crosta formando magmas a partir de fusões parciais e fracionamento magmático inicialmente ácidas seguida de pulsos básicos (Fig. 7). 

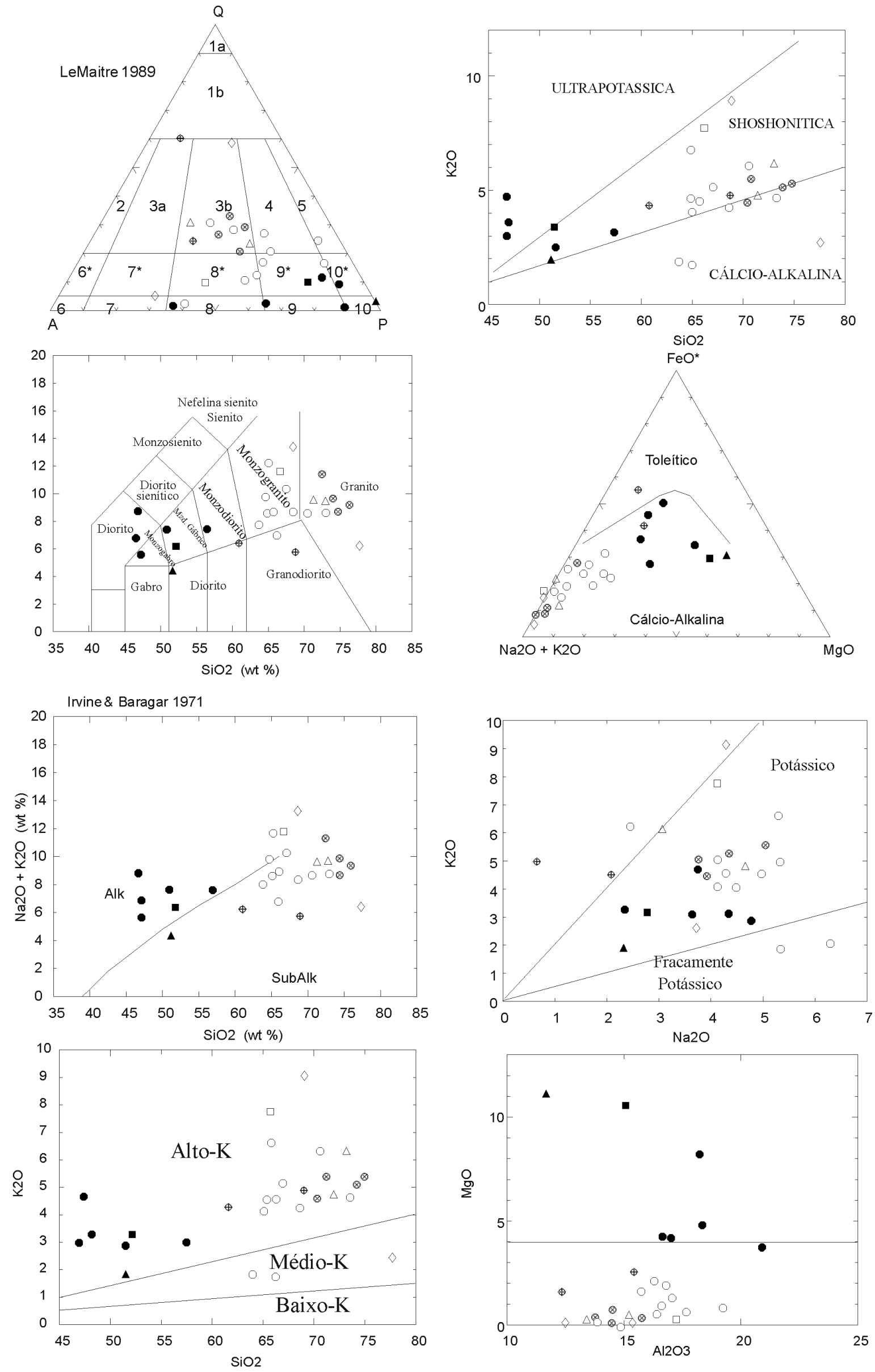

Figura 5 - Diagramas classificatórios para as rochas do Arco Magmático de Pereiro. 

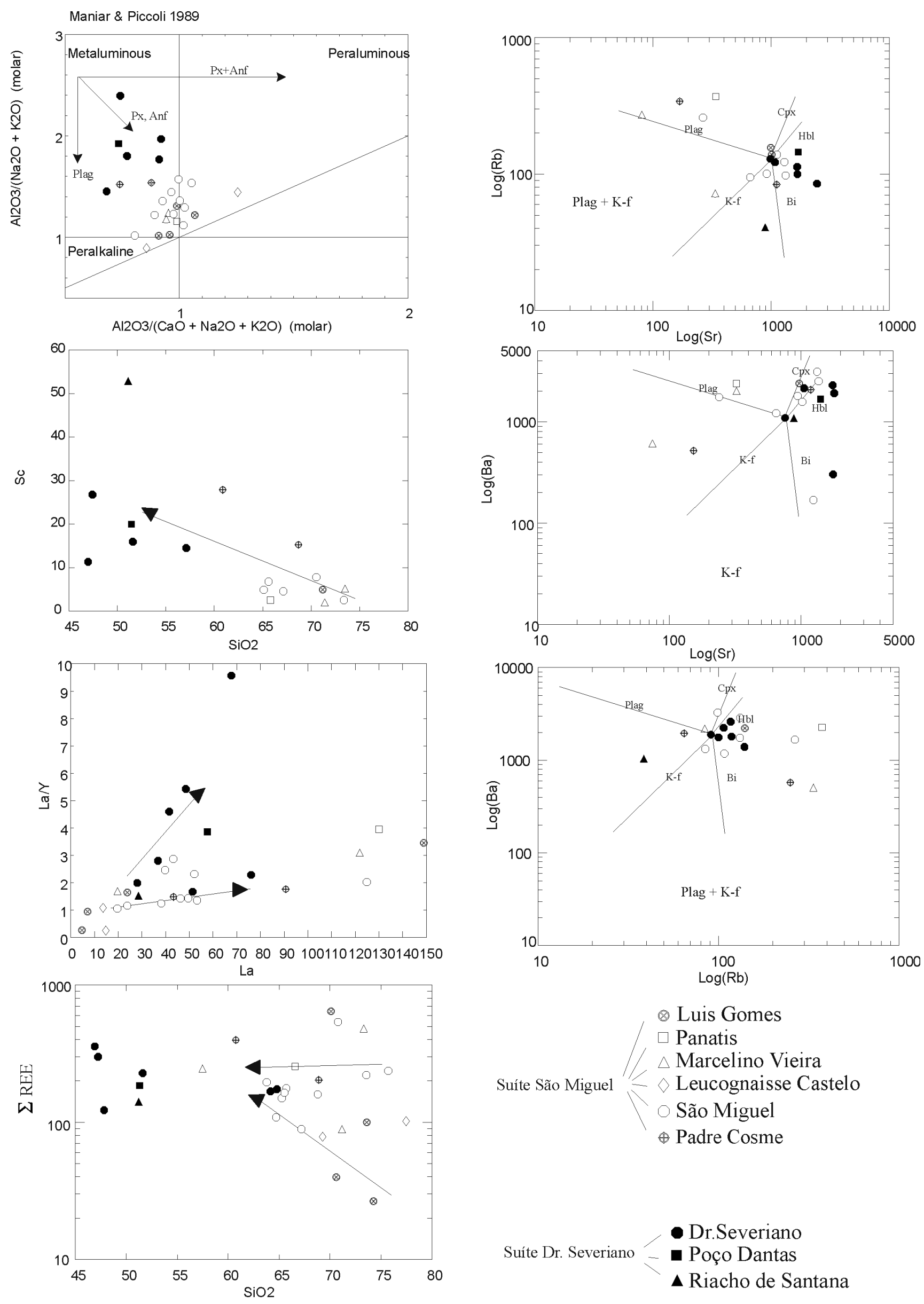

Figura 6 - Diagramas de classificação serial e fracionamento mineral para as rochas do AMP. 

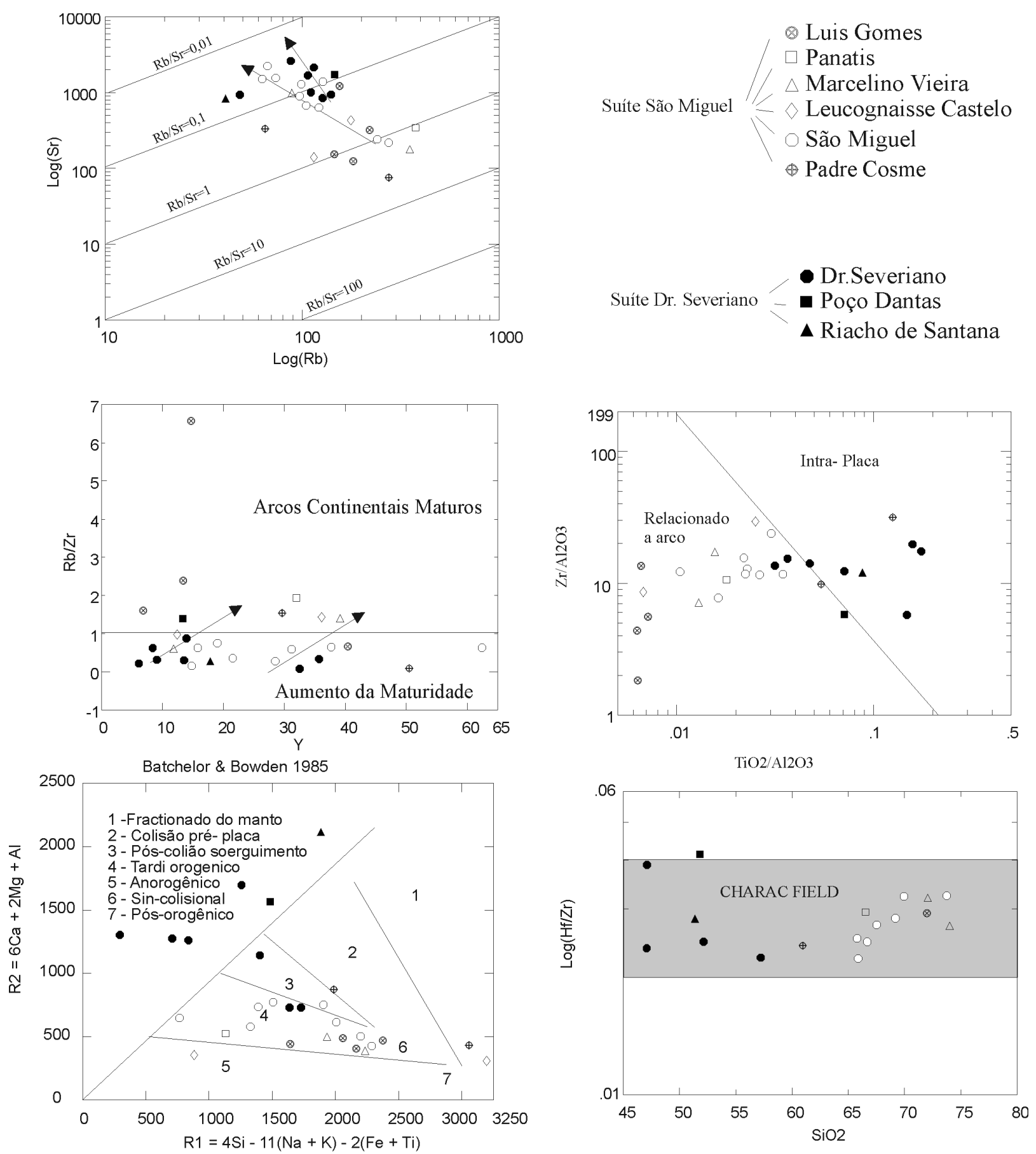

Figura 7 - Diagramas de classificação tectônica e impulsos magmáticos para as rochas do Arco Magmático de Pereiro.

Quanto a ambiência tectônica (relação $\mathrm{Zr}$ / A12O3 vs TiO2/A12O3; segundo Batchelor e Bowden 1985 ) as rochas da SSM são predominantemente associadas a arcos intra placa de caraterísticas sin-colisionais a tardi-tectônicos. As rochas da SDS (dioritos e gabros) possuem características intra-placa respectivamente associados a arcos continentais e arcos póscolisionais. Embora possuam características diferentes em relação ao ambiente tectônico todos os granitóides analisados possuem características de formação dos magmas contaminados por material mantélico, segundo o diagramas $\mathrm{SiO}_{2}$ vs $\mathrm{Hf} / \mathrm{Zr}$ (Fig. 7) e de uma forma ou de outra estão intimamente relacionados a geração de arcos magmáticos plutônicos.

As análises de ETR observadas nos aranhogramas (Fig. 8) apresentam para a SSM forte enriquecimento em ETRL, em relação aos ETRP. Idintificou-se anomalias negativas de $\mathrm{Eu}, \mathrm{Ti}, \mathrm{Nb}$ e positivas de $\mathrm{Sr}, \mathrm{Ba}$, $\mathrm{Nd}$, já o Th apresenta-se variável. As anomalias negativas indicam fracionamento de plagioclásio ou efeito da 

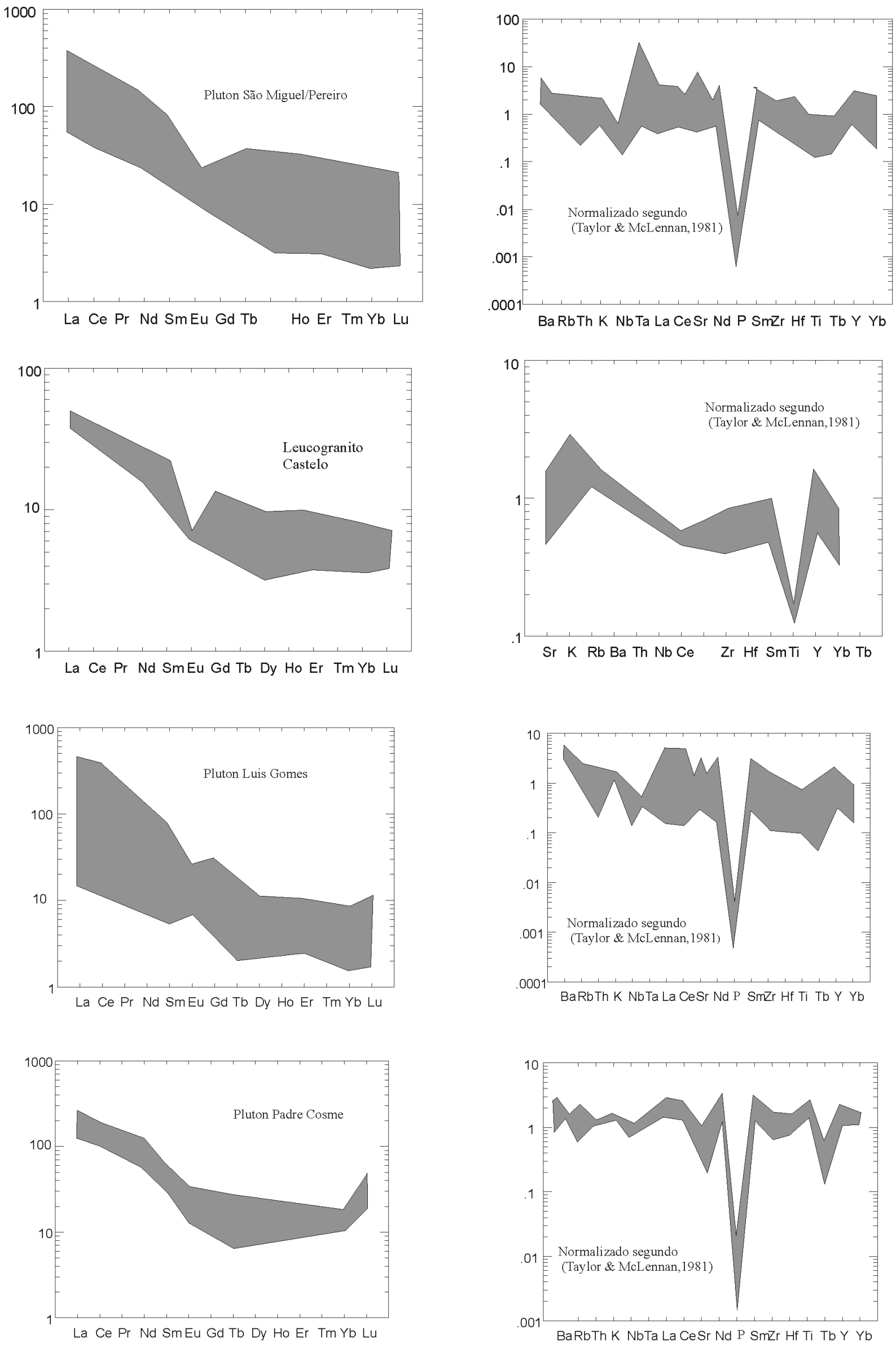

Figura 8 - Padrões ETR série La-Lu e Spiderdiagrams ,para as rochas do Arco Magmático de Pereiro, Suite São Miguel, normalizados para condrito. 
fusão fracionada tratando-se de magmas secundários, as anomalias positivas indicam que a fonte destes magmas possuem ampla contribuição de fonte crustal. Na SDS os padrões apresenta repetido enriquecimento em ETRL em relação aos ETRP e as porém as anomalias positivas se invertem. Não ocorre anomalia negativas de Eu, o Ti mostra-se enriquecido em relação aos valores da SSM.
O Th apresenta anomalias negativas, o Sr apresenta forte anomalia positiva juntamente com o $\mathrm{Ba}$.

Os padrões invertidos mostram que as fontes de cada suíte, pulso magmático são diferentes. A SSM possui padrões ETR de protólitos crustais enquanto que a SDS apresenta padrão misto, crustal e mantélico (Fig. 9).
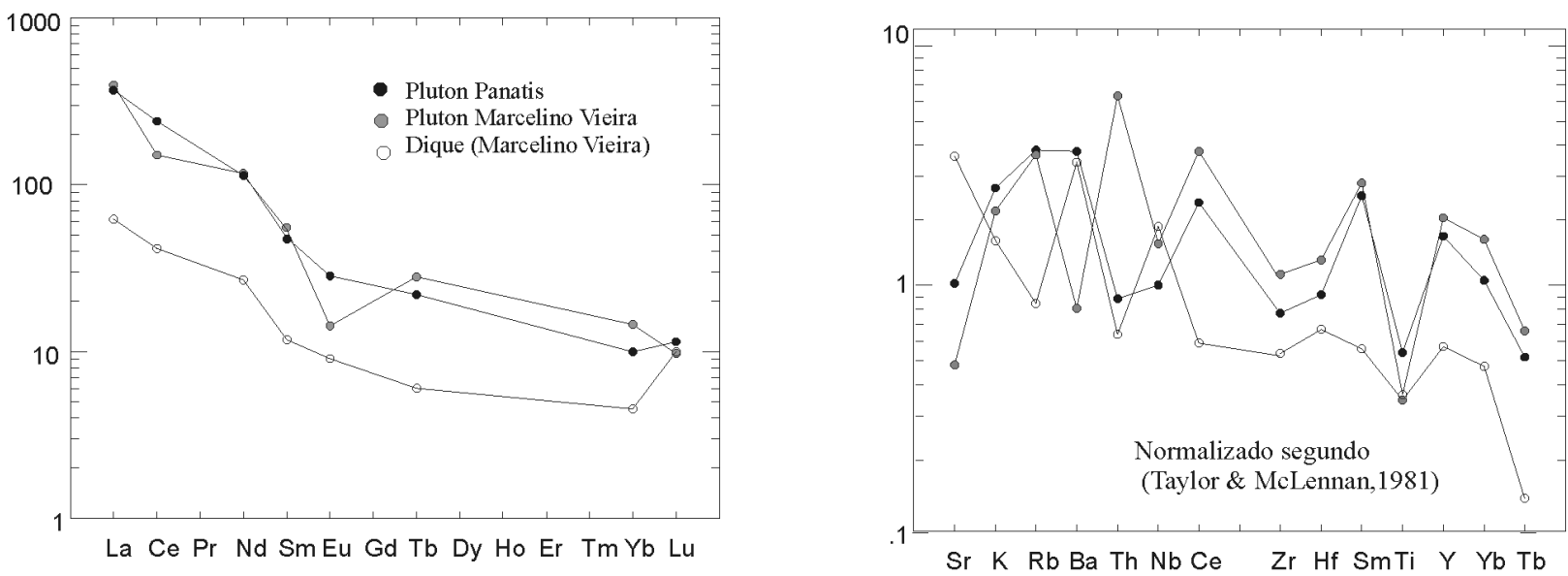

\section{Suíte Dr Severiano}
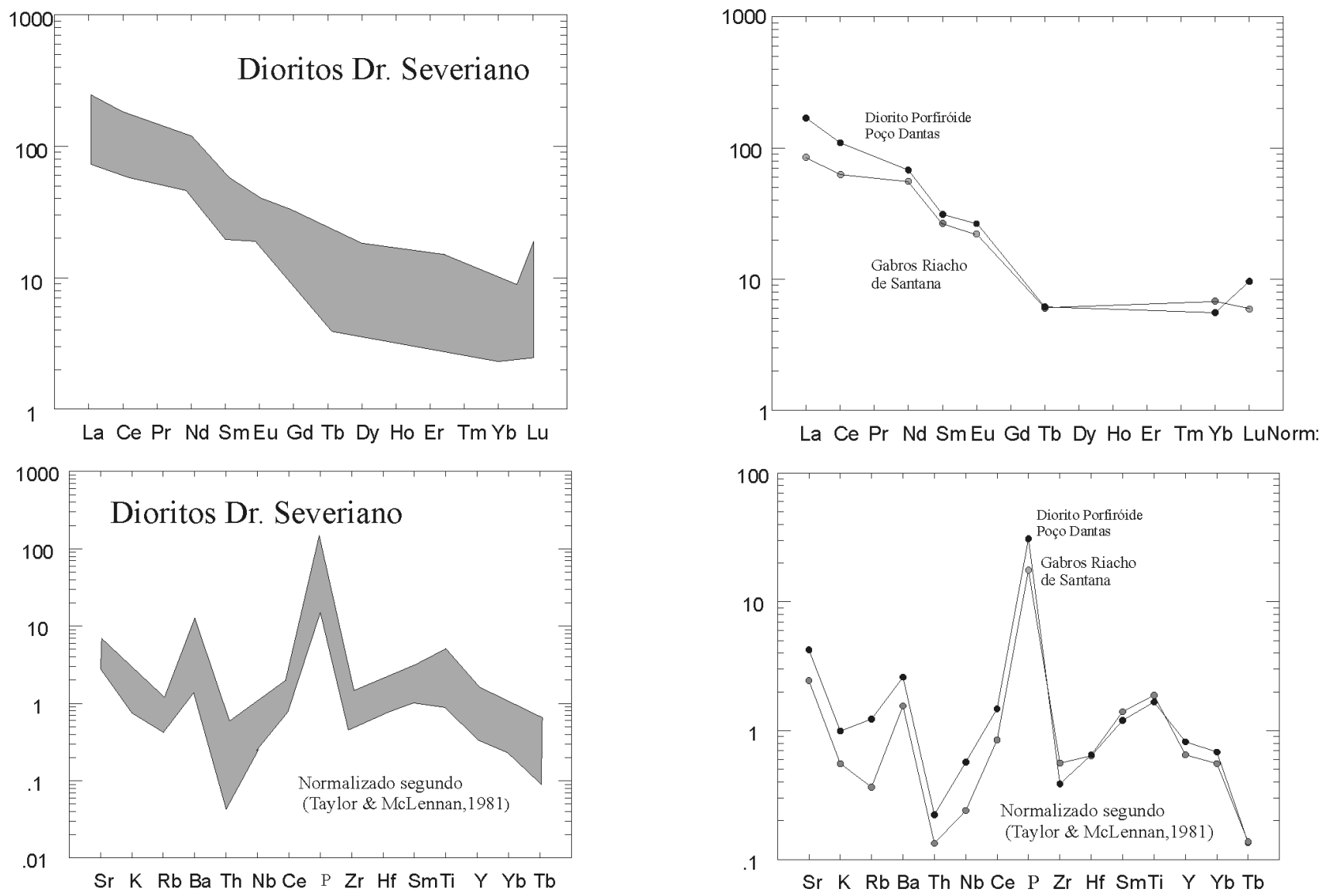

Figura 9 - Diagramas série La-Lu e spiderdiagrams para rochas da Suite São Miguel (Plutons Panatis, Marcelino Vieira e diques) e da Suíte Dr Severiano do Arco Magmático de Pereiro. 
GEOCRONOLOGIA Foram realizados alguns métodos isotópicos que auxiliaram na interpretação evolutiva da geologia da área, buscamos analisar idades de cristalização e dos protólitos, utilizando os métodos $\mathrm{U} / \mathrm{Pb}$ (zircões) e Sm/Nd (rocha total). Na SSM foi datado através do método U/Pb o batólito São Miguel/Pereiro, este com idade de $571.8 \pm 2.8 \mathrm{Ma}$ com MSWD $=1.5$, e o Pluton Padre Cosme, este com idade de $560 \pm 60 \mathrm{Ma}$ com MSWD = 1.84 (Magini 2001). Quanto aos dados Sm/Nd obtidos em rocha total nas duas suítes apresentaram valores $\mathrm{T}_{\mathrm{DM}}$ entre de $2.70 \mathrm{Ga}$ a $2.25 \mathrm{Ga}$ para os granitóides da SSM, e $\mathrm{T}_{\mathrm{DM}}$ que variam de $2.34 \mathrm{Ga}$ a $2.04 \mathrm{Ga}$ para os granitóides da SDS (Fig. 10). A pequena diferença entre os $\mathrm{T}_{\mathrm{DM}}$ de cada suíte atesta em caráter mais tardio para a SDS corroborando com as informações de campo e tectônicas de que o pulso básico é posterior ao pulso ácido. Outro dados a ser analisado com mais detalhe nos resultados $\mathrm{U} / \mathrm{Pb}$ no batólito São Miguel/Pereiro são os valores da concórdia no intercepto superior com idades de $1.7 \mathrm{Ga}$. O protólito pelo menos do magma desta suíte sofreu forte contribuição de rochas de idade de $1.7 \mathrm{Ga}$, as quais são existentes na área, expressas pelo Grupo São José e Faixa Orós-Jaguaribe mais a oeste. Este valor tem mais relevância geotectônica quando concluímos que no contexto regional terrenos de $1.7 \mathrm{Ga}$ são inexistentes a leste do arco magmático de Pereiro.

CONCLUSÕES Os estudos de geoquímica e geocronologia utilizados nesta pesquisa foram aplicados em outros arcos magmáticos no Brasil por inúmeros autores (Galindo et al. 1997 Wernick 1999, Oliveira et al. 2006) e no mundo (Tarmey e Suanders 1990, Müller et al. 1992, Stern \& Hanson 1991). No estado do Ceará Fetter (1999) sumariza a geocronologia na região do Domínio Ceará Central região N-NW no estado do Ceará, identifica e denomina de Arco Magmático de Santa Quitéria formados por terrenos com granitos e metassedimentos neoproterozóicos.

No Arco Magmático de Pereiro modelamos sua gênese a partir da análise temporal (geocronologia), características geoquímicas e isotópicas, efeitos da tectônica e do metamorfismo, procurando assim montar sua evolução geológica com o maior números possível de informações.

Temporalmente os magmas do AMP começam a ser formar no Ciclo Brasiliano, a cristalização magmática ocorre entre $570 \mathrm{Ma}$ e $530 \mathrm{Ma}$, formando um intervalo de 40 ma desenvolvido de forma monocíclica no neoproterozóico. Algumas possibilidades de nos estudos devem se extender no conhecimento da pegmatização que representa o último evento magmático do arco, os resultados podem aumentar esta amplitude de 40 Ma. Os protólitos da SSM são principalmente neoarqueanos variando entre $2.7 \mathrm{Ga}, 2.5 \mathrm{Ga}$ e paleoproterozóicos $2.3 \mathrm{Ga}$, nas rochas da SDS os valores são todos paleoproterozóicos $2.0 \mathrm{Ga}$ e $2.1 \mathrm{Ga}$.

Os magmas do AMP fundiram-se em meio à rochas encaixantes de idade neoarquenas, paleoproterozóicas e estaterianas como o Complexo Jaguaretama, Complexo Pau dos Ferros e Faixas Orós-Jaguaribe.

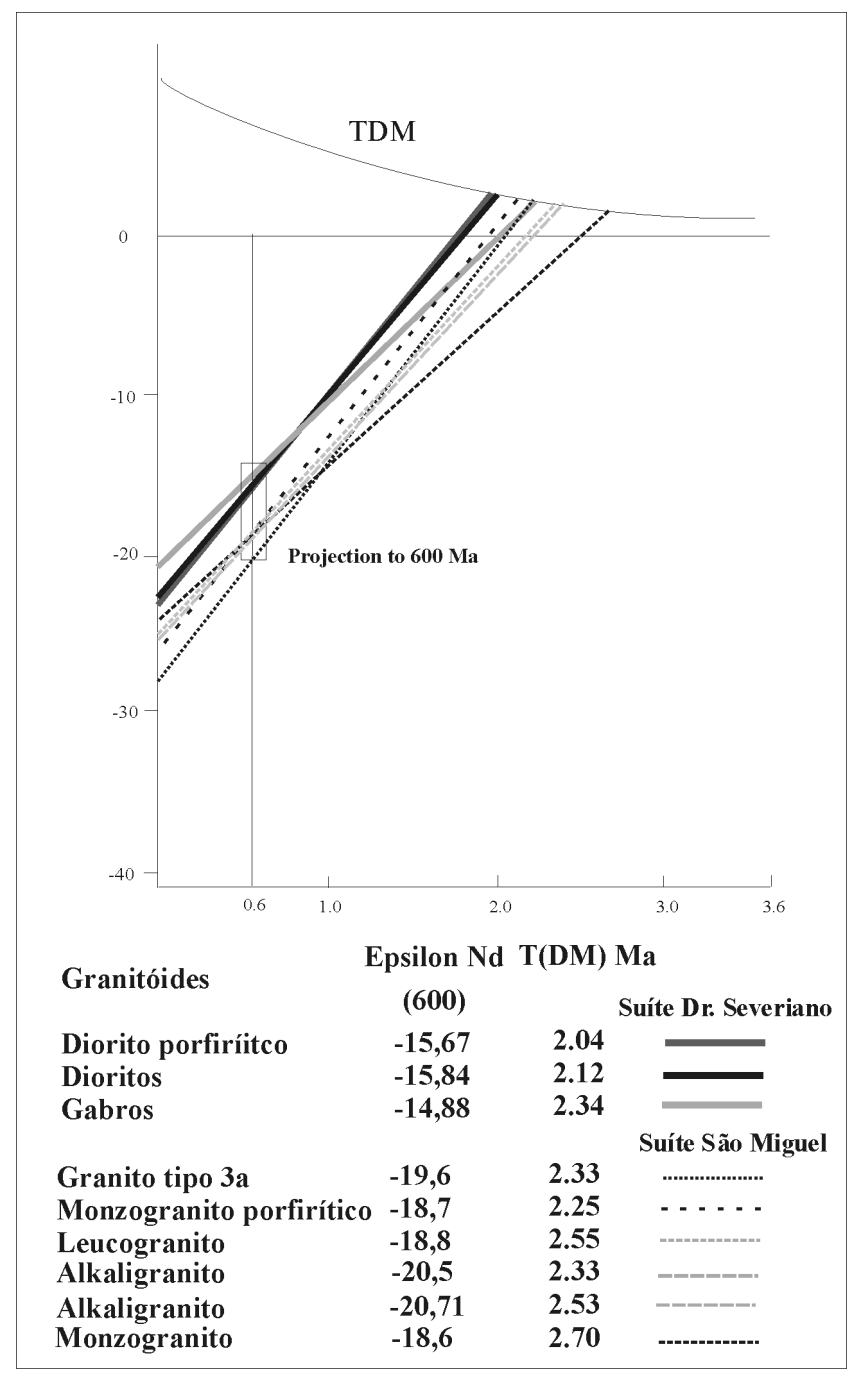

Figura 10 - Diagrama de evolução do Nd para as rochas do Arco Magmático de Pereiro.

Terrenos estaterianos ocorrem a oeste do AMP que permite ao menos inferir que ocorreu uma convergência de oeste pata leste, quer seja por subducção, detachment ou underplateing das seqüências de Orós/Jaguaribe/ São José. Posteriormente este conjunto foi retrabalhado pelos processos tectonometamórficos do Brasiliano.

$\mathrm{O}$ arco é formado por rochas cálcio-alcalinas a alcalinas de alto a médio potássio. Os padrões ETR nas duas suítes mostram enriquecimento de ETR leves em relação aos ETR pesados. Anomalias inversas entre rochas da SSM e rochas da SDS corroboram para atestar que o arco se edificou com magmas de origens diferentes. Este fato leva a formação de rochas com caráter híbrido com protólitos derivados da crosta continental e crosta continental + manto litosférico, fato este observado nos padrões ETR das duas suites. No arco o modelo geotectônico evoluiu inicialmente com a colocação de magmas da SSM (monzogranitos) em sistemas de baixo ângulo (cavalgamentos) passando para alto ângulo (trasncorrências), ambos em deformação dúctil. A 
SDS é menos deformada exibindo feições rúpteis com magmas colocados em sistemas de alto ângulo tarditranscorrências. A evolução tectônica juntamente com a assinatura geoquímica permite concluir a ocorrência de um sistema colisional, com acresção de sequências vulcano-sedimentares do tipo rifte, com metassomatismo e formação de fundidos (granitos neoproterozóicos) da paleocrosta e topo do manto. A contaminação por fonte mantélica foi possível ascender devido ao afinamento crustal promovido pelos sistemas de transcorrências regionais os quais funcionaram como up flyt tantas vezes observadas com padrões geométricos de flôr positiva e negativa (Fig. 11).

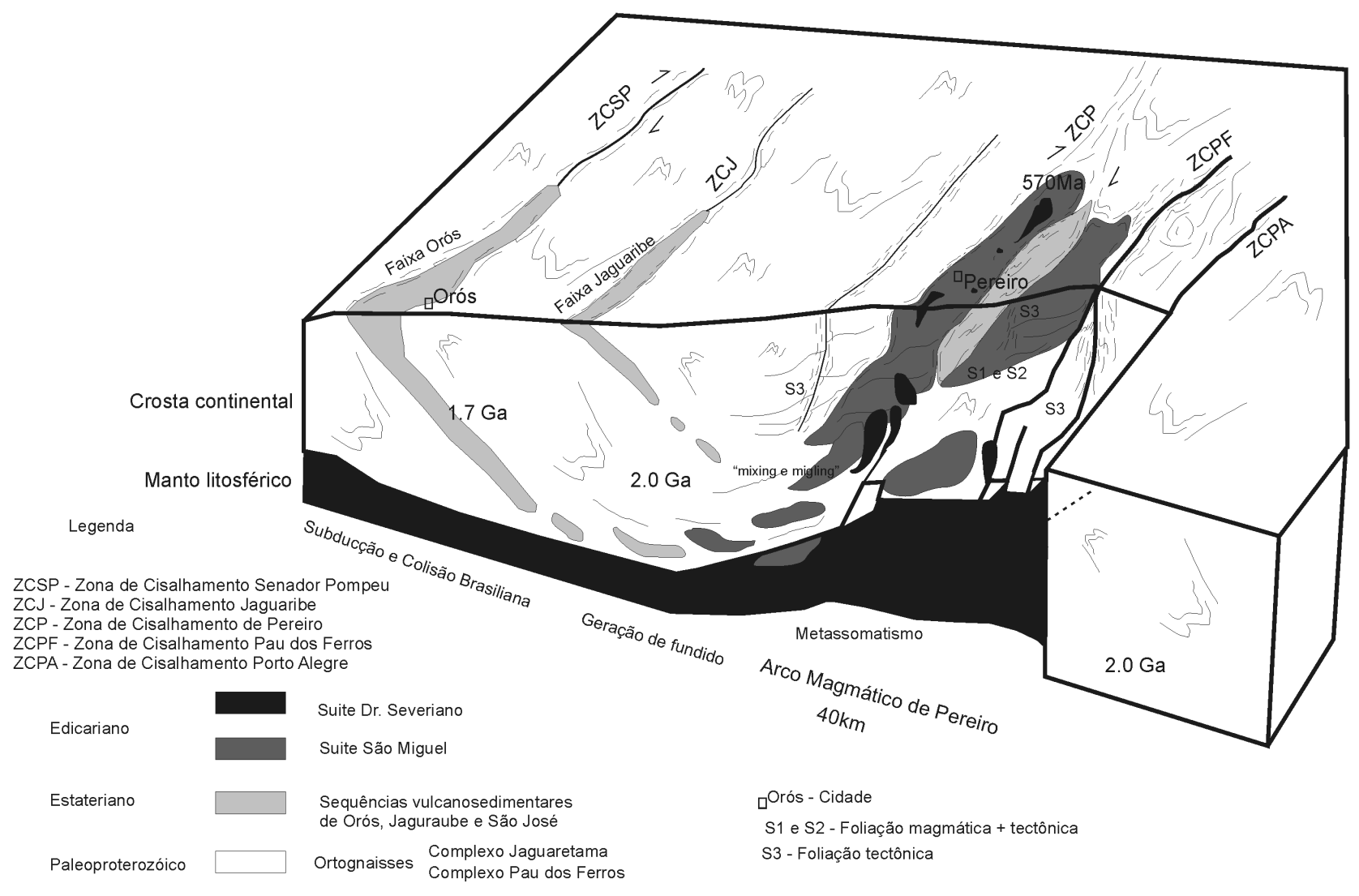

Figura 11 - Modelo de perfil crustal da região de Pereiro - CE com embasamento paleoproterozóico, sequências vulcanosedimenatres estaterianas e magmatismo granítico de idade edicariana (Arco Magmático de Pereiro).

Agradecimentos CNPq, Fapesp, Unesp, Univ. Kansas, Lawrence, USP, UFRN, UFC.

\section{Referências}

Batchelor R.A. \& Bowden P. 1985. Petrogenetic interpretation of granitoids rock series using milticationic parameters. Chemical Geology, 48:216-221.

Cavalcante J.C. \& Sá J.M. de. 1997. A sequência Peixe Gordo no contexto da Faixa Jaguaribeana, Província Borborema, NE Brasil. In: Simp. Geol. Nord. Fortaleza, 17, Atas, p16-19.

Dantas E.L. 1992. Evolução Tectono-Magmática do Maciço Polidiapírico São Vicente/Florânia-RN. Dissertação de Mestrado UNESP, Rio Claro (SP), p.272.
Fetter A.H. 1999. U-Pb and Sm/Nd geocronological constraints on the crustal freamework and geologic history of Ceará State, NW Borborema Province, NE Brazil: Implications of the assembly Gondwana. Tese de Doutoramento, Departamento de Geologia, Universidade de Kansas, Lawrence USA, 164p.

Figueiredo O.A. de F. 1994. Geoquímica e Geocronologia de Metavulcânicas e Metagranitóides dos cinturões Orós e Jaguaribe, SE do Ceará. Tese de Doutoramento, IG-USP, São Paulo, 159p. 
Galindo A.C., Jardim de Sá E.F., Nascimento R.S.C., Holanda M.H.B.M., Nascimento M.A.L., Lardeux J.M. 1997. Caracterização geoquímica e contexto geodinâmico dos granitóides alcalinos na porção oridental da Faixa Seridó (RN, PB). In: SBG/Núcleo Nordeste, Simp. Geol. Nordeste, 17, Fortaleza, Atas, 16:263-267.

Hackspacher P.C., Legrand J.M., Petta R.A., Magini C., Dantas E.L. 1992. O Batólito São Vicente/Caicó - RN. In: Cong. Bras. Geol., 37, São Paulo, Anais, 2:143.

Hutton D.H.W. 1988. Granitic emplacement mechanisms and tectonic controls: inferences from deformation studies. The Royal Soc. Edenburgh E. Sci., 79:245-255.

Irivine T.N., Baragar W.R.A. 1971. A guide to the chemical classification of the common volcanic rocks. Can. J. Earth Sci., 8:523-48.

Le Meitre R.W., Le Bas M.J., Streckeisen A., Zanettin B. 1989. A chemical classification of volcanic rocks based on the total alkali-silica diagram. J. Petrol., 27:745-50.

Magini C., Santos T.S., Neves B.B. de B., Hackspacher P.C., Schmus W.R., Dantas E.L., Fetter A.H. 1999. Statherian Taphrogenesis in the Borborema Province, NE Brazil. In: Saagi, 2, Córdoba, Argentina. p. 327-330.

Magini C., Neves B. B. de B., Hackapscher P., Dantas E.L., Fetter A.R. 2000 Isotopic evolution of a Brasiliano Plutonic Complex in the northern portion of Borborema Province, São Miguel region, RN, Brazil. In: Int. Cong. Geol, Rio de Janerio, Anais, CD-Rom.

Magini C. 2001. Evolução Pré-Cambriana da Província Borborema: O Extremo Oeste Potiguar. Tese de Doutoramento. IGCE, Unesp, Rio Claro, 218p.

Magini C. \& Hackspacher P.C. 2006. Evolução Metamórfica de Arcos Magmáticos Neoproterozóicos: Região NE da Província Borborema. Revista de Geologia UFC, 2: 71-86.

Maniar P.D. \& Piccoli P.M. 1989. Tectonic discrimination of granitoids. Geological Society of America Bulletin, 101:635-643.

Müller D., Rock N.M.S., Groves D.I. 1992. Geochemical Discrimination Between Shoshonitic and Potassic Volcanic Rocks in Different Tectonic Settings: a Pilot Study. Mineralogy and Petrology, 46:259-289.

Neves B.B. de B., Winge M., Carneiro M.A. 1996. Orogêneses precedendo e Tafrogêneses sucedendo Rodínia na América do Sul. Bol. IG-USP Sér. Cient., 27:1-40.

Neves B.B. de B., Sá J.M., Nilson A.A, Botelho N.F. 1998. A Tafrogênese Estateriana nos blocos Paleoproterozóicos da América do Sul e processos subsequentes. Geonômos, 3(2):1-21.

Neves B.B. de B. 1999. América do Sul quatro fusões e quatro fissões e o processo acrescionário Andino. Rev. Bras. Geoc., 29:379-392.

Oliveira M. A. de, Dall'Agnol R., Althoff F.J. 2006. Petrografia e geoquímica do Granodiorito Rio Maria da região de Bannach e comparações com as demais ocorrências no terreno granito-greenstone de Rio Maria -
Pará. Rev. Brás. Geoc., 36(2):313-326.

Pitcher W.S. 1975. Granite type and Tectonic Environment. In: Hsu K.J. (ed.) Mountains Building Process. London, Academic Press, p.19-40.

Ramsay J.G. \& Huber M.I. 1987a. The techniques of modern structural geology - I: Strain Analysis.Academic Press, p.1-308.

Ramsay J.G. \& Huber M.I. 1987b. The techniques of modern strucutral geology - II: Folds e fractures. Academic Press, 308-700.

Sá E.F.J., Legrand J.M., Sá C.A.S., Lira C.P., Neto F.A.M., Rego J.M., Souza L.C. 1981. Esboço da geologia PréCambriana do Extremo Oeste Potiguar. In: Simp. Geol. Nord., 10, Recife, p. 315-328.

Sá J.M. 1991. Evolution Geodynamic de la ceinture proterozoic d'Orós, Nord-Est du Brésil. Tese de Doutoramento. IG-USP, São Paulo, 189p.

Schmus W.R.V., Neves B.B. de B., Hackspacher P.C., Babinsky M. 1995. U/Pb and $\mathrm{Sm} / \mathrm{Nd}$ geochronolgic studies of the eastern Borborema Province, Northeastern Brazil: inital conclusions. Journal South Amer. Sc., 8(3/4):267-288.

Schmus W.R.V., Neves B.B. de B., Willians I.S., Hackspacher P.C., Fetter A.H., Dantas E.L., Babinsky M. 2003. The Serido Group of NE Brazil: Late Neoproterozoic, precolisonal flysch basin in West Godwanaland-insights from Shirimp U-Pb detrital zircon ages. Precambrian Research, 127:287-327.

Stern A.L. \& Hanson G. 1991. Archean high-Mg granodiorite: a derived, LILE-enriched Archean monzodiorite and trachyandesites (sanukitoids) in Southwestern Superior Province. Canadian Journal of Earth Sciences, 26:16881712.

Streickeisen A.L. 1967. Classification and nomenclature of igneuos rocks. N. Jb. Min. Abh., 107(2/3):144-240.

Tarmey J. \& Saunders A. 1990. Crustal growth mechanisms and mantle evolution. In: International Archean Symposium, 3, Perth, Austrália, Extended Abstract, Geoconferences, p. 451-452.

Taylor S.R., Arculus R., Perfit M.R., Johnson R. 1981. Island arc basalts. In: Basaltic volcanism in the Terrestrial Planets (Basaltic Volcanism Study Project). New York, Pergamon Press, p. 193-213.

Wernick E. 1999. K-rich rocks from the Pluriserial Magmatic Ribeira System-590: Genetic aspects and isotopic implications.. In: South American Symposium on Isotopic Geology, 2, Cordoba, Argentina. Actas, 1:278-282.

Manuscrito AE 096/2006 Submetido 21 de agosto de 2007 Aceito em 23 de junho de 2008 